\title{
Evaluating the Toxicity of Ionic Liquids on Shewanella sp. for Designing Sustainable Bioprocesses
}

\author{
Hakima Kebaili ${ }^{1,2 *}$, Antonia Pérez de los Ríos ${ }^{1}$, María José Salar-García ${ }^{3 *}$, \\ Víctor Manuel Ortiz-Martínez ${ }^{3 *}$, Mostefa Kameche ${ }^{2}$, Jesús Hernández-Fernández ${ }^{1}$ and \\ Francisco J. Hernández-Fernández ${ }^{1 *}$
}

${ }^{1}$ Department of Chemical Engineering, Faculty of Chemistry, University of Murcia (UMU), Murcia, Spain, ${ }^{2}$ Laboratory of PhysicoChemistry of Materials, Catalysis and Environment, Faculty of Chemistry, University of Sciences and Technology of OranMohamed Boudiaf, Oran, Algeria, ${ }^{3}$ Department of Chemical and Environmental Engineering, Technical University of Cartagena (UPCT), Campus La Muralla, Cartagena, Spain

\section{OPEN ACCESS}

Edited by: Emilia Morallon,

University of Alicante, Spain

Reviewed by:

Adil Denizli,

Hacettepe University, Turkey

Guillermo Díaz-Sainz,

University of Cantabria, Spain

*Correspondence:

María José Salar-García

mariajose.salar@upct.es

Francisco J. Hernández-Fernández

fjhernan@um.es

Hakima Kebail

kebailihakima@gmail.com

Victor Manuel Ortiz-Martínez victor.ortiz@upct.es

Specialty section: This article was submitted to Biomaterials,

a section of the journal

Frontiers in Materials

Received: 01 July 2020 Accepted: 13 October 2020 Published: 27 November 2020

Citation:

Kebaili H, Pérez de los Ríos A, SalarGarcía MJ, Ortiz-Martínez VM, Kameche M, Hernández-Fernández $J$ and Hernández-Fernández FJ (2020) Evaluating the Toxicity of Ionic Liquids

on Shewanella sp. for Designing

Sustainable Bioprocesses.

Front. Mater. 7:578411.

doi: 10.3389/fmats.2020.578411
Ionic liquids (ILs) are widely used as reaction and separation media in many technologies due to their unique and advantageous physicochemical properties. Thus, further studies approaching the study of the toxicity of these materials are required. Moreover, they are utilized in devices in which microorganisms such as Shewanella sp. act as biocatalysts. Thus, in this work, the toxicity of 69 ILs on the marine bacterium Shewanella sp. was tested. Specifically, the ILs analyzed were based on the cations imidazolium, pyridinium, pyrrolidinium, piperidinium, morpholinium, oxazolinium, phosphonium, ammonium, and sulfonium, in combination with different anions. The toxicities of this wide group of ILs on Shewanella sp. were determined using two methods: 1) the agar disk-diffusion test and 2) the growth inhibition test in liquid media. The relationship between toxicity and IL chemical structure was elucidated. A decrease in the hydrophobicity of the alkyl chain length was found to be a key factor to reduce IL toxicity. On the other hand, phosphonium-based ILs containing long alkyl chains were shown to be largely incompatible with Shewanella sp.

Keywords: ionic liquids, toxicity, Shewanella sp, sustainable materials, biocompatibility

\section{HIGHLIGHTS}

- ILs as clean and green alternatives to organic solvents in bioprocesses

- Screening IL toxicity toward Shewanella sp. for bioprocess applications

- Analysis of chemical structure contributions to IL toxicity toward Shewanella sp.

- Tool for the adequate cation/anion combination to synthesis nontoxic ILs

\section{INTRODUCTION}

The genus Shewanella was first described in 1931. This microorganism responsible for butter putrefaction was initially named as Achromobacter putrefaciens but after further studies and biochemical characterizations, the species isolated in 1931 was then reclassified into a new genus, Shewanella (Derby and Hammer, 1931; MacDonell and Colwell, 1985). So far, all members belonging to this genus are facultatively anaerobic, which allows them to survive in a wide variety of environments, although they are usually found in aquatic or marine habitats (Hau 
and Gralnick, 2007). One of the main characteristics of the Shewanella genus is its capability to grow at low temperatures. Although most of the strains are psychrotolerant with optimum growth temperature above $16^{\circ} \mathrm{C}$, many strains are psychrophilic and can easily grow below this temperature (Hau and Gralnick, 2007). The capability of Shewanella to use several external electron acceptors to respire, which enables this genus to live in extreme conditions, as well as the possibility of being genetically modified, has boosted its application in a wide variety of technological fields (Hau and Gralnick, 2007; Marsili et al., 2008; Zou et al., 2019), from bioremediation of polluted environments (Varia et al., 2014; Zhang et al., 2018) and biosensing (Webster et al., 2014) to bioenergy production in microbial fuel cell technology (Jorge and Hazael, 2016; Kumar et al., 2016).

Ionic liquids (ILs) are combinations of cations (i.e., imidazolium, pyridinium, and ammonium) and anions (i.e., hexafluorophosphate, tetrafluoroborate, and bis [(trifluoromethyl)sulfonyl]imide) that remain liquid at temperatures below $100^{\circ} \mathrm{C}$. In recent years, these compounds have drawn the attention of the scientific community due to their unique properties such as negligible vapor pressure, chemical and thermal stability, nonflammability, high ionic conductivity, wide electrochemical potential window, and solvation ability, among other features (Ventura et al., 2012b). ILs are also considered clean and green alternatives to organic solvents mainly due to their low vapor pressure, which prevents their release into the atmosphere. Besides, their physical and chemical properties can be adapted to specific applications by the fine-tuning of the cation structure and by selecting proper cation-anion combinations. Since a wide variety of ion combinations are possible, it is of the highest importance to outline rational guidelines to develop technologically suitable but also environmentally harmless ILs (Latała et al., 2009).

The emergence of ILs as solvents has instigated several new and exciting areas of scientific research including organic synthesis (Welton, 1999; Earle et al., 2008), catalysis (Welton, 1999; Pârvulescu and Hardacre, 2007), electrodeposition (Endres, 2002; Zein El Abedin et al., 2006; El Abedin and Endres, 2007), dye-sensitized solar cells (Gorlov and Kloo, 2008), and lubrication (Ye et al., 2001). Moreover, within the field of nanotechnology, ILs have been synthesized with finely tuned nanoscopic structures for the preparation of polymers (Haddleton et al., 2008; Kim et al., 2008), nanoparticles (Dupont et al., 2002; Schrekker et al., 2007), nanotubes (Barisci et al., 2004; Shim and Kim, 2009), and microemulsions (Eastoe et al., 2005; Qiu and Texter, 2008). ILs are currently being investigated worldwide for cutting edge applications, especially for electrochemical devices and energy production such as lithium batteries (Sakaebe et al., 2005; Ishikawa et al., 2006), electrochemical capacitors (Balducci et al., 2005), electrochemical actuators (Ding et al., 2003), and light-emitting electrochemical cells (Yang et al., 2003). In the field of biocatalysis, ILs have been used free of solvent (Toral et al., 2007; de los Ríos et al., 2012; Lee et al., 2015), adsorbed (Hernández et al., 2006; Lee et al., 2007; Jiang et al., 2009; Zou et al., 2014), and covalently linked to particles enzymes (Lozano et al., 2010; Suo et al., 2018; Xiang et al., 2018) or as polymeric ILs (Nakashima et al., 2009) in enzyme particles, in all cases to create an adequate enzyme microenvironment and improve the catalytic efficiency (Hernández et al., 2006; Toral et al., 2007; Lozano et al., 2010; de los Ríos et al., 2012; Lee et al., 2015). ILs and Shewanella sp. have been recently used together in microbial fuel cell technology for bioenergy production (Zhao et al., 2013; Wei et al., 2016) and the biofabrication of nanoparticles (Wang et al., 2018). Due to the enormous range of IL application and the multiple benefits of including bacteria in certain types of bioprocesses, it is crucial to address the biocompatibility of ILbased materials for progress in the design of sustainable processes.

In this context, this work investigates the biocompatibility of ILs containing different cation and anion structures toward Shewanella sp. Thus, the toxicity of a total number of 69 ILs based on imidazolium, pyridinium, pyrrolidinium, piperidinium, morpholinium, oxazolinium, phosphonium, ammonium, and sulfonium combined with different anions has been analyzed in solid and liquid media. The results obtained are in-depth discussed and related to the structural characteristic of the ILs, which enables identifying key factors for the design of environmentally friendly ILs with lower ecotoxicological risks than conventional organic solvents.

\section{MATERIALS AND METHODS}

\section{Ionic Liquids}

The ILs investigated in the current work are grouped according to the type of cation present in their structure. Tables 1-8 include the name of each IL analyzed, together with its structure and water solubility. These tables also include the nomenclature used for each IL (abbreviation name). All ILs were supplied by IoLiTec (Ionic Liquids Technologies).

\section{Culture of Shewanella sp.}

The strain of Shewanella sp. was provided by the Aquatic Ecology Laboratory (University of Murcia, Spain) and kept on LuriaBertani Agar (LB). A single colony was used to grow the inoculum on LB broth at $25^{\circ} \mathrm{C}$ with shaking at $200 \mathrm{rpm}$. All chemicals and media reagents were purchased from Sigma-Aldrich.

\section{Toxicity Analysis}

The toxicity of 69 ILs toward Shewanella sp. was analyzed by using two different methods: 1) agar disk-diffusion test and 2) toxicity in liquid media. Both methods are described below.

\section{Agar Disk-Diffusion Test}

The agar disk-diffusion method was used for the first time in 1940 by Heatley (Heatley, 1944) being now the most common technique for determining the antimicrobial properties of many compounds (Balouiri et al., 2016). So far, a wide variety of bacteria has been successfully tested by this method by varying the culture media and the incubation conditions as well as the evaluation criteria for the inhibition zones (Clinical and Laboratory Standards Institute, 2015). This method consists of 
TABLE 1 | Imidazolium-based ionic liquids.

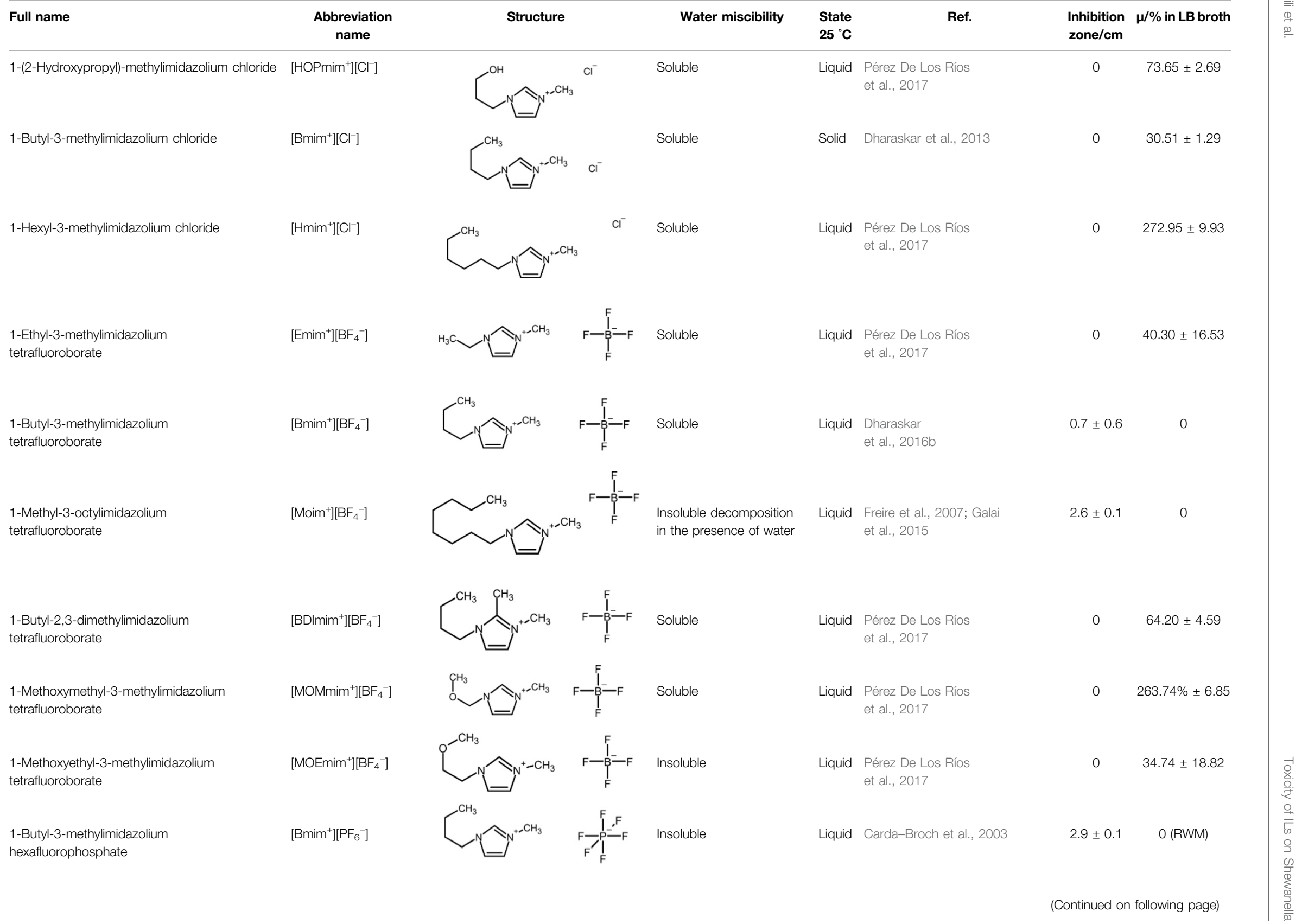


TABLE 1 | (Continued) Imidazolium-based ionic liquids.

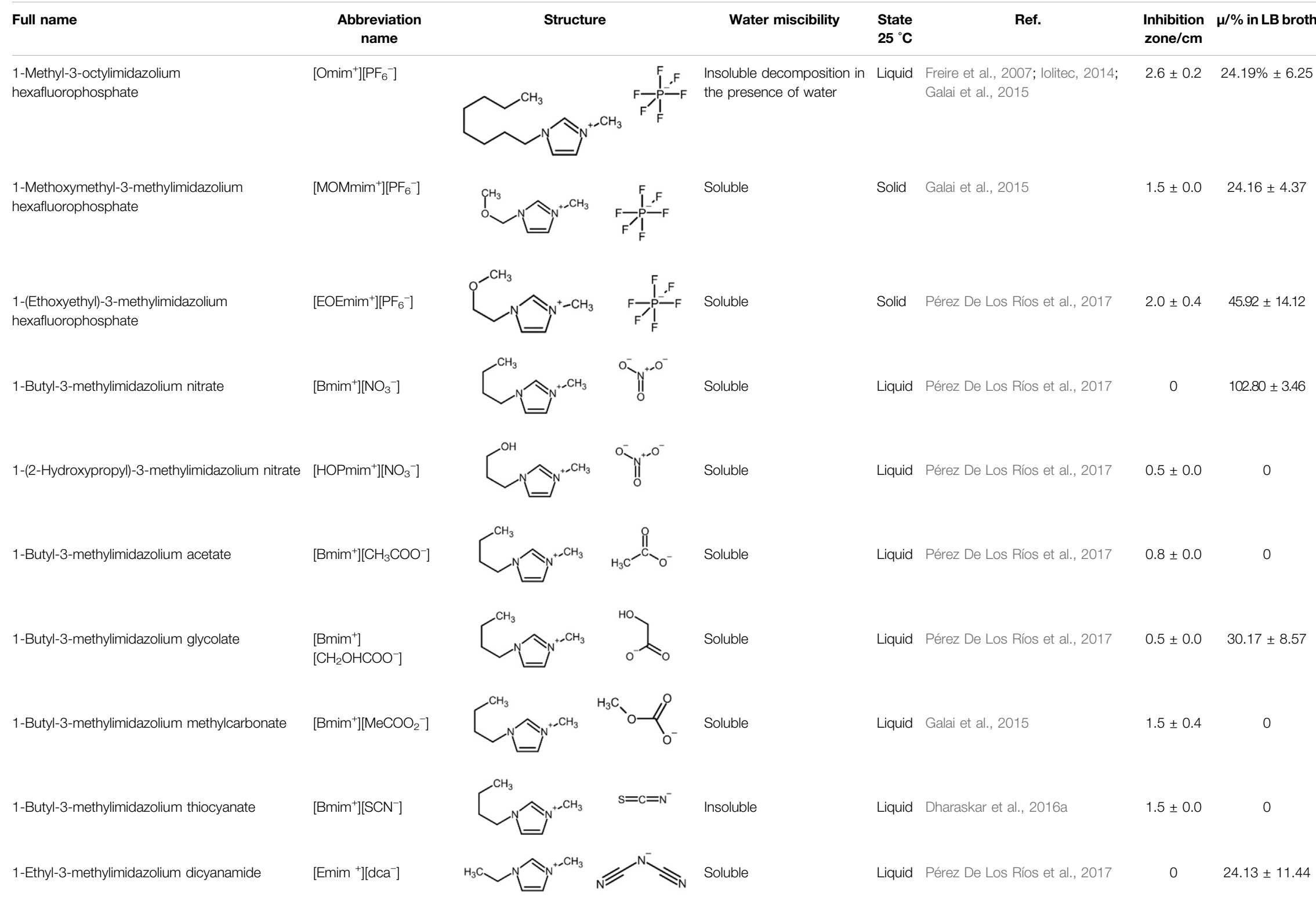


TABLE 1 | (Continued) Imidazolium-based ionic liquids.

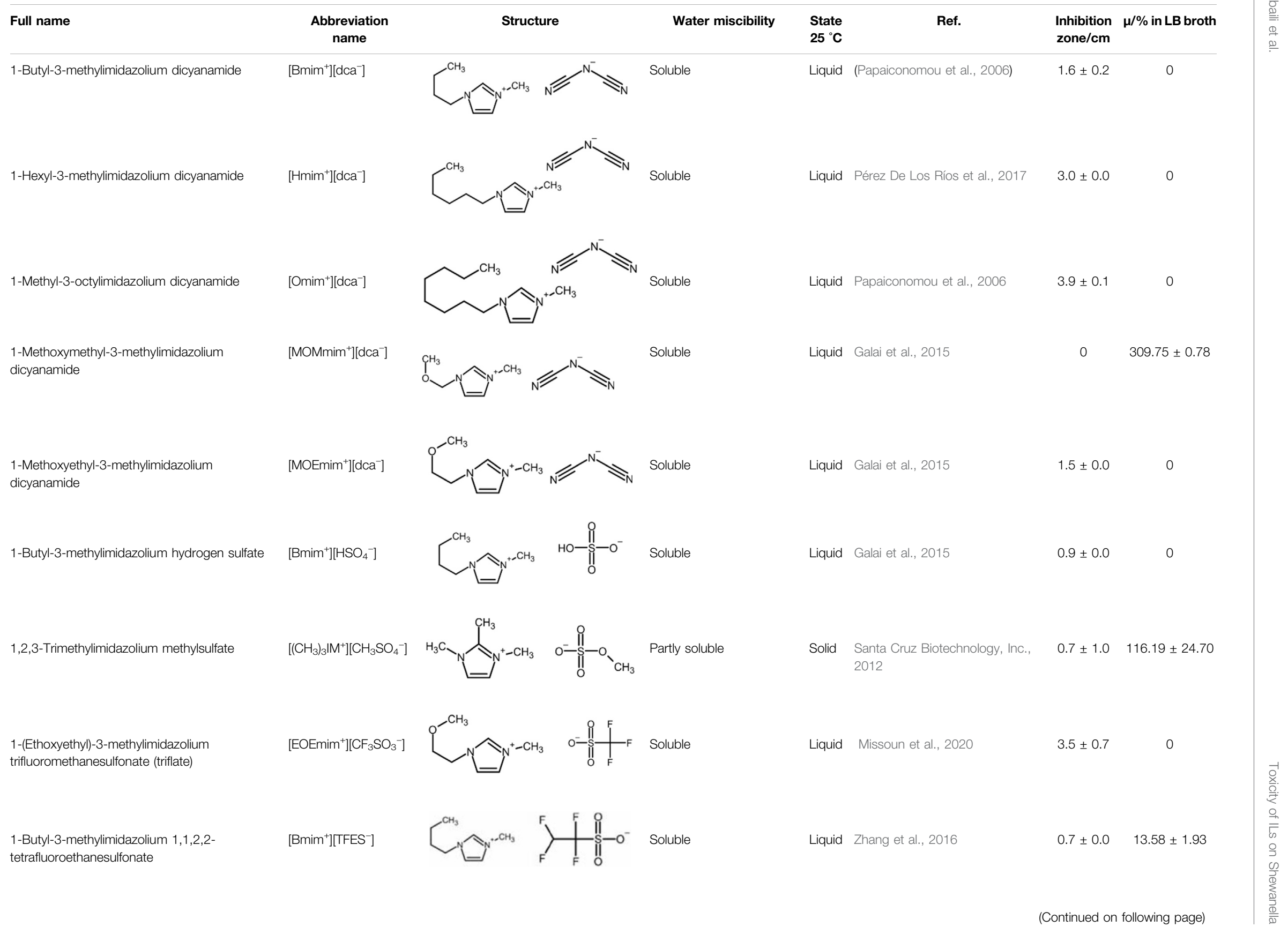




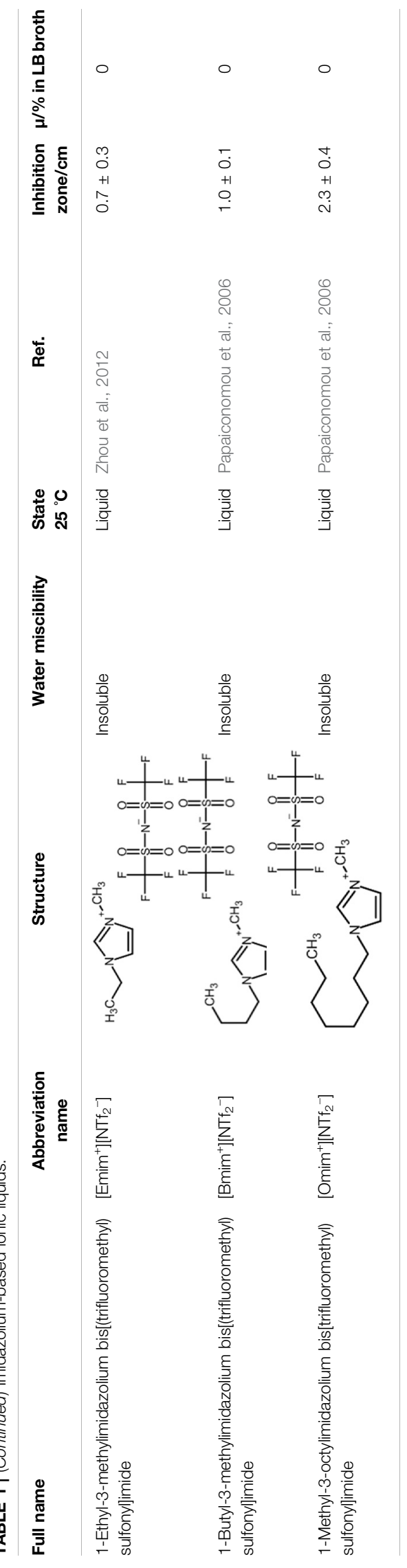

inoculating agar plates with a standardized inoculum of a specific microorganism. Then, the test compound embedded in small pieces of filter paper was placed on the agar surface and the Petri dishes were incubated under suitable conditions for the growth of the microorganisms. Finally, the antimicrobial activity of the test compound was evaluated according to the diameter of the inhibition growth zone. Although this method is not entirely satisfactory to determine the minimum inhibitory concentration (MIC), it brings many advantages over other techniques such as its simplicity and suitability to assess the compatibility between a wide variety of compounds and microorganisms as well as its low cost (Balouiri et al., 2016).

Due to the great interest of the scientific community in the search for new and safe applications of ILs, the agar disk-diffusion method has also been used to determine the biocompatibility of these green solvents (Rebros et al., 2009; Ventura et al., 2012a). Thus, this procedure was selected to evaluate the inhibitory capacity of a wide variety of ILs on the growth of Shewanella sp. To this end, $100 \mu \mathrm{l}$ of Shewanella sp. culture incubated overnight was spread on an LB agar plate. Each IL was added to sterile, preweighted disks of filter paper (around $6 \mathrm{~mm}$ of diameter), and then placed on the surface of the Petri agar dish. ILs in solid-state were weighed and then sterile-distilled water was added dropwise until the salt was completely dissolved. An aliquot of $5 \mu \mathrm{l}$ of the salt solution was added to the disk of filter paper and the amount embedded ranged between 0.004 and $0.0125 \mathrm{~g}$. All Petri dishes were incubated overnight in a static incubator at $25^{\circ} \mathrm{C}$, and the radius of the inhibition zone around the filter paper was measured according to Rebros et al. (2009). Each IL was tested in triplicate and the inhibition zones reported in the present work are the average of the three replicates unless otherwise stated.

\section{Toxicity in Liquid Media}

To delve into the biocompatibility of the ILs with Shewanella sp., an alternative method based on measuring the growth rates in LB broth medium containing yeast extract, peptone, glucose, and $\mathrm{NaCl}$ in the presence and absence of IL was used. In order to decrease the viscosity, water-miscible ILs were weighed and mixed with sterile-distilled water to produce a stock solution $(95 \% \mathrm{w} / \mathrm{v})$. Viscous ILs along with those with unusual phase behavior were also prepared in the same way. The stock solutions were vortexed before adding an aliquot of $40 \mu \mathrm{l}$ to the microcultures up to a final concentration of $2 \%(\mathrm{v} / \mathrm{v})$. Nonviscous water-immiscible ILs were added directly to the cultures by volumetric measurement to produce a biphasic system $2 \% \mathrm{v} / \mathrm{v}$. The cultures were inoculated with $100 \mu \mathrm{l}$ from an overnight culture of Shewanella sp. grown in the same medium. The flasks were incubated for $24 \mathrm{~h}$ at $25^{\circ} \mathrm{C}$ with continuous and intensive shaking.

The optical density (OD) of each culture was measured every $2 \mathrm{~h}$ and the growth curve was determined for each case. The specific growth rate $\left(\mu, \mathrm{h}^{-1}\right)$ was calculated by selecting two points at times $t_{1}$ and $t_{2}$ in the exponential growth phase and applying the following equation:

$$
\mu=\frac{\operatorname{In}\left(\mathrm{OD}_{2} / \mathrm{OD}_{1}\right)}{t_{1}-t_{2}} .
$$


TABLE 2 | Pyridinium-based ionic liquids.

\begin{tabular}{|c|c|c|c|c|c|c|c|}
\hline Full name & Abbreviation name & Structure & Water miscibility & State $25^{\circ} \mathrm{C}$ & Ref. & $\begin{array}{l}\text { Inhibition } \\
\text { zone/cm }\end{array}$ & $\mu / \%$ in LB broth \\
\hline 1-Butyl-3-methylpyridinium tetrafluoroborate & {$\left[\mathrm{BMPy}^{+}\right]\left[\mathrm{BF}_{4}^{-}\right]$} & & Soluble & Liquid & Ortega et al., 2007; Galai et al., 2015 & 0 & $232.69 \pm 4.22$ \\
\hline 1-Butyl-3-methylpyridinium dicyanamide & {$\left[\mathrm{BMPy}^{+}\right]\left[\mathrm{dca}^{-}\right]$} & & Soluble & Liquid & $\begin{array}{l}\text { Bandrés et al. 2008; Kalčíková } \\
\text { et al., 2012; Galai et al., } 2015\end{array}$ & $1.0 \pm 0.0$ & $155.18 \pm 34.40$ \\
\hline 1-Methyl-3-octylpyridinium dicyanamide & {$\left[\mathrm{MOPy}^{+}\right]\left[\mathrm{dca}^{-}\right]$} & & Insoluble & Liquid & Galai et al., 2015 & $1.1 \pm 0.0$ & 0 \\
\hline 1-Methylpyridinium methylsulfate & {$\left[\mathrm{MPy}^{+}\right]\left[\mathrm{MeSO}_{4}^{-}\right]$} & & Soluble & Solid & Galai et al., 2015 & 0 & $170.77 \pm 9.85$ \\
\hline 1,4 dimethyl pyridinium methylsulfate & {$\left[\mathrm{MMPy}^{+}\right]\left[\mathrm{Me} \mathrm{SO}_{4}^{-}\right]$} & & Soluble & Solid & Galai et al., 2015 & $1.8 \pm 0.4$ & $317.77 \pm 9.99$ \\
\hline 1-Ethylpyridinium ethyl sulfate & {$\left[\mathrm{EPy}^{+}\right]\left[\mathrm{EtSO}_{4}^{-}\right]$} & & Soluble & Liquid & Benito et al., 2014; Galai et al., 2015 & 0 & $286.16 \pm 10.19$ \\
\hline 1-Ethylpyridinium bis [(trifluoromethyl)sulfonyl]imide & {$\left[\mathrm{EPy}^{+}\right]\left[\mathrm{NTf}_{2}{ }^{-}\right]$} & & Insoluble & Liquid & $\begin{array}{l}\text { Benito et al., 2014; Galai } \\
\text { et al., 2015; Iolitec, } 2015 b\end{array}$ & $0.9 \pm 0.0$ & $19.68 \pm 5.83$ \\
\hline
\end{tabular}


TABLE 3 | Pyrrolidinium-based ionic liquids.

\begin{tabular}{|c|c|c|c|c|c|c|c|}
\hline Full name & $\begin{array}{l}\text { Abbreviation } \\
\text { name }\end{array}$ & Structure & $\begin{array}{l}\text { Water } \\
\text { miscibility }\end{array}$ & State $25^{\circ} \mathrm{C}$ & Ref. & $\begin{array}{l}\text { Inhibition } \\
\text { zone/cm }\end{array}$ & $\begin{array}{l}\mu / \% \text { in LB } \\
\text { broth }\end{array}$ \\
\hline 1-Butyl-1-methyl pyrrolidinium chloride & {$\left[\mathrm{BMPyr} \mathrm{r}^{+}\right]\left[\mathrm{Cl}^{-}\right]$} & & Soluble & Solid & $\begin{array}{l}\text { Galai et al., 2015; Iolitec, } \\
\text { 2015a }\end{array}$ & $0.9 \pm 0.0$ & 0 \\
\hline $\begin{array}{l}\text { 1-Butyl-1-methyl pyrrolidinium } \\
\text { hexafluorophosphate }\end{array}$ & {$\left[\mathrm{BMPyr}^{+}\right]\left[\mathrm{PF}_{6}{ }^{-}\right]$} & & Insoluble & Solid & $\begin{array}{l}\text { Iolitec, 2011c; Ventura et al., } \\
2013\end{array}$ & $0.8 \pm 0.0$ & 0 \\
\hline 1-Butyl-1-methyl pyrrolidinium dicyanamide & {$\left[\mathrm{BMPyr}^{+}\right]\left[\mathrm{dca}^{-}\right]$} & & Soluble & Liquid & $\begin{array}{l}\text { Iolitec, 2011b; Cumicheo } \\
\text { et al., } 2015\end{array}$ & 0 & $88.78 \pm 14.74$ \\
\hline 1-Butyl-1-methyl pyrrolidinium triflate & {$\left[\mathrm{BMPyr}^{+}\right]\left[\mathrm{TFO}^{-}\right]$} & & Soluble & Liquid & $\begin{array}{l}\text { Iolitec, 2012b; Fadeeva et al., } \\
2015\end{array}$ & 0 & $106.33 \pm 4.44$ \\
\hline $\begin{array}{l}\text { 1-Ethyl-1-methyl pyrrolidinium } \\
\text { bis[(trifluoromethyl)sulfonyl]]imide }\end{array}$ & {$\left[\mathrm{EMPyr}{ }^{+}\right]\left[\mathrm{NTf}_{2}{ }^{-}\right]$} & & Insoluble & Solid & $\begin{array}{l}\text { Galai et al., 2015; lolitect, } \\
2011\end{array}$ & $1.3 \pm 0.3$ & 0 \\
\hline $\begin{array}{l}\text { 1-Butyl-1-methyl pyrrolidinium } \\
\text { bis[(trifluoromethyl)sulfonyl]jimide }\end{array}$ & {$\left[\mathrm{BMPyr}^{+}\right]\left[\mathrm{NTf}_{2}^{-}\right]$} & & Insoluble & Liquid & $\begin{array}{l}\text { Iolitec, 2011a; Fadeeva et al., } \\
2015\end{array}$ & $2.2 \pm 1.2$ & $14.33 \pm 6.31$ \\
\hline
\end{tabular}


TABLE 4 | Piperidinium-based ionic liquids.

\begin{tabular}{|c|c|c|c|c|c|c|c|}
\hline Full name & Abbreviation name & Structure & Water miscibility & $\begin{array}{l}\text { State at } \\
25^{\circ} \mathrm{C}\end{array}$ & Ref. & $\begin{array}{l}\text { Inhibition } \\
\text { zone/cm }\end{array}$ & $\mu / \%$ in LB broth \\
\hline $\begin{array}{l}\text { 1-Butyl-1-methylpiperidinium bis[(trifluoromethyl)sulfonyl] } \\
\text { imide }\end{array}$ & {$\left[\mathrm{BMPi}^{+}\right]\left[\mathrm{NTf}_{2}{ }^{-}\right]$} & & Insoluble & Liquid & Iolitec, 2012a; Galai et al., 2015 & $1.6 \pm 0.1$ & 0 \\
\hline
\end{tabular}

TABLE 5 | Morpholinium-based ionic liquids.

\begin{tabular}{|c|c|c|c|c|c|c|c|}
\hline Full name & $\begin{array}{l}\text { Abbreviation } \\
\text { name }\end{array}$ & Structure & $\begin{array}{c}\text { Water } \\
\text { miscibility }\end{array}$ & State at $25^{\circ} \mathrm{C}$ & Ref. & $\begin{array}{l}\text { Inhibition } \\
\text { zone/cm }\end{array}$ & $\begin{array}{l}\mu / \% \text { in LB } \\
\text { broth }\end{array}$ \\
\hline $\begin{array}{l}\text { Ethyl methyl morpholinium } \\
\text { dicyanamide }\end{array}$ & {$\left[\mathrm{EMMOR}^{+}\right]\left[\mathrm{dca}^{-}\right]$} & & Soluble & Liquid & $\begin{array}{l}\text { Russina et al., 2013; Peréz de los Ríos et al., } \\
2017\end{array}$ & 0 & $3.95 \pm 1.72$ \\
\hline
\end{tabular}

TABLE 6 | Oxazolinium-based ionic liquids.

\begin{tabular}{lllclll}
\hline Full name & Abbreviation name & Structure & Water miscibility & State at $\mathbf{2 5}{ }^{\circ} \mathbf{C}$ & Ref. \\
\hline Methyloxazolinium methylsulfate & {$\left[\mathrm{Moxa}^{+}\right]\left[\mathrm{MeSO}_{4}^{-}\right]$} & Soluble & Liquid & Galai et al., 2015; Peréz de los Ríos et al., 2017 \\
\hline
\end{tabular}


TABLE 7 | Ammonium-based ionic liquids.

\begin{tabular}{|c|c|c|c|c|c|c|c|c|}
\hline Full name & Abbreviation name & Structure & & $\begin{array}{l}\text { Water } \\
\text { miscibility }\end{array}$ & $\begin{array}{l}\text { State at } \\
25^{\circ} \mathrm{C}\end{array}$ & Ref. & $\begin{array}{l}\text { Inhibition } \\
\text { zone/cm }\end{array}$ & $\begin{array}{l}\mu / \% \text { in LB } \\
\text { broth }\end{array}$ \\
\hline Methyltrioctylammonium chloride & {$\left[\mathrm{N}_{8,8,8,1}{ }^{+}\right]\left[\mathrm{Cl}^{-}\right]$} & & $\mathrm{Cl}^{-}$ & Insoluble & Liquid & $\begin{array}{l}\text { Sigma Aldrich, 2006; Galai et al., } \\
2015\end{array}$ & $3.0 \pm 0.7$ & 0 \\
\hline
\end{tabular}

Choline dihydrogen phosphate

$\left[\mathrm{Chol}^{+}\right]\left[\mathrm{H}_{2} \mathrm{PO}_{4}^{-}\right]$

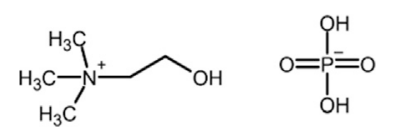

Soluble

Solid

Iolitec, 2012c; Galai et al., 2015

0

$146 \pm 0.15$

N,N-dimethylbutylammonium 2-hexyldecanoate

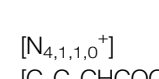

$\left[\mathrm{C}_{8} \mathrm{C}_{6} \mathrm{CHCOO}^{-}\right]$

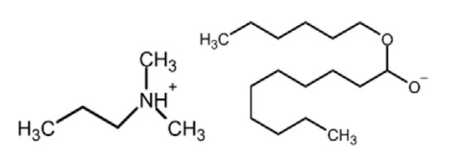

Soluble

Liquid Walker, 2009

$0.5 \pm 0.7$

0

$\left[\mathrm{N}_{8,8,8,1^{+}}\right]\left[\mathrm{CF}_{3} \mathrm{SO}_{3}^{-}\right]$

Insoluble

Solid

Iolitec, 2012d; Galai et al., 2015

$1.4 \pm 0.5$

$179.23 \pm 6.72$

trifluoromethanesulfonate

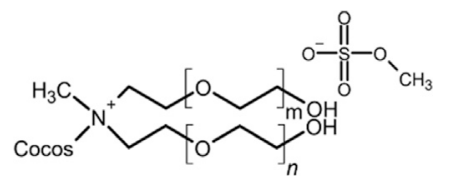

Soluble

Liquid

Galai et al., 2015; Illitec, 2015d

$3.5 \pm 0.7$

Cocosalkylpentae
methylsulfate

$$
m, n=5-10
$$

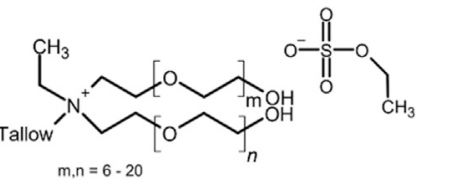

Insoluble

Liquid Iolitec, 2010; Galai et al., 2015

$2.8 \pm 0.1$

0

methylsulfate

[C1EG1]$$
\overbrace{\mathrm{H}_{3} \mathrm{C}_{\mathrm{O}}}^{\mathrm{Cl}^{-}}
$$

Soluble

Liquid Galai et al., 2015; Iolitec, 2015c

$39.12 \pm 3.16$

Choline bis[(trifluoromethyl)sulfonyl]imide

$\left[\mathrm{Chol}^{+}\right]\left[\mathrm{NTf}_{2}{ }^{-}\right]$ 
TABLE 8 | Phosphonium-based ionic liquids.

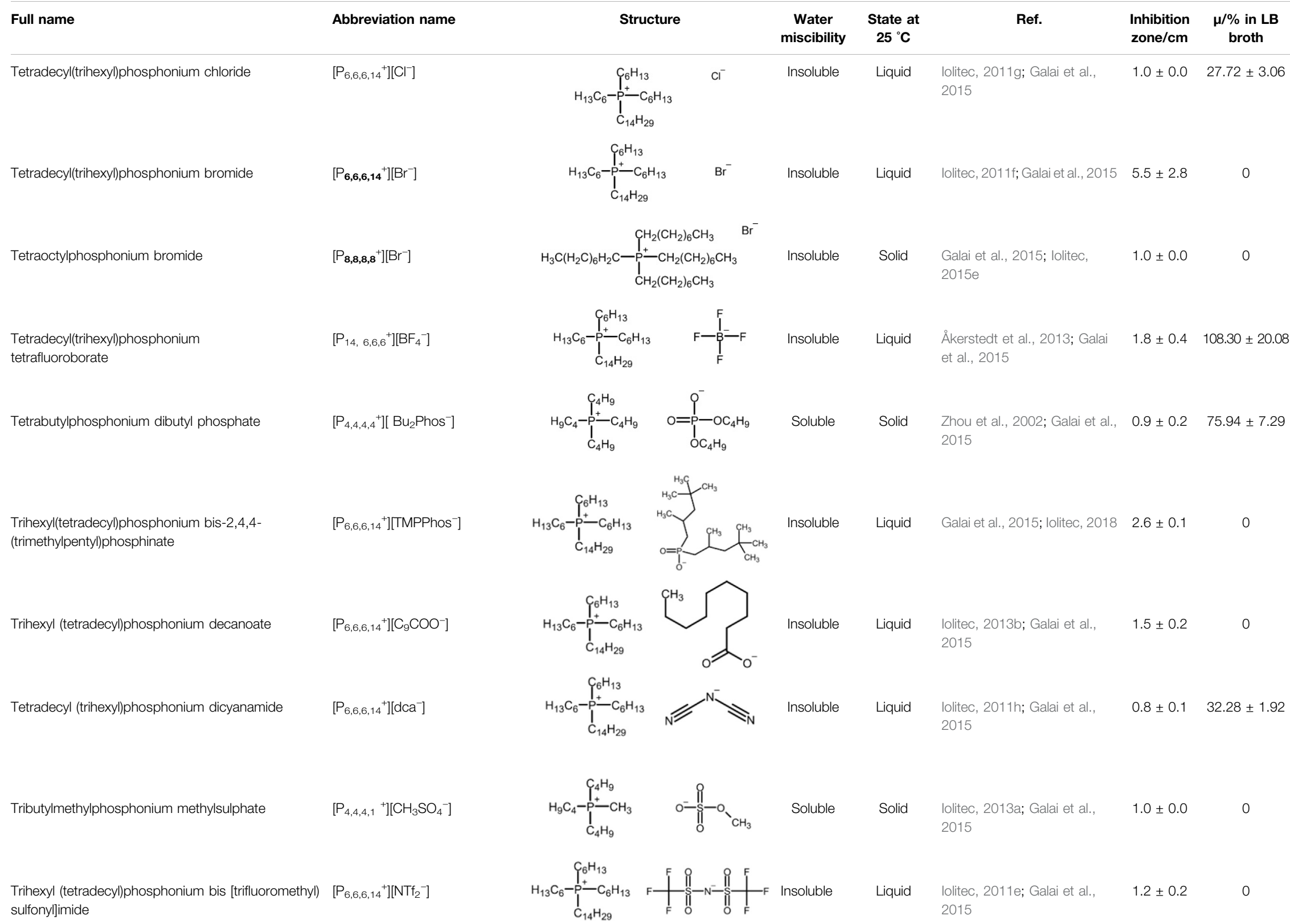




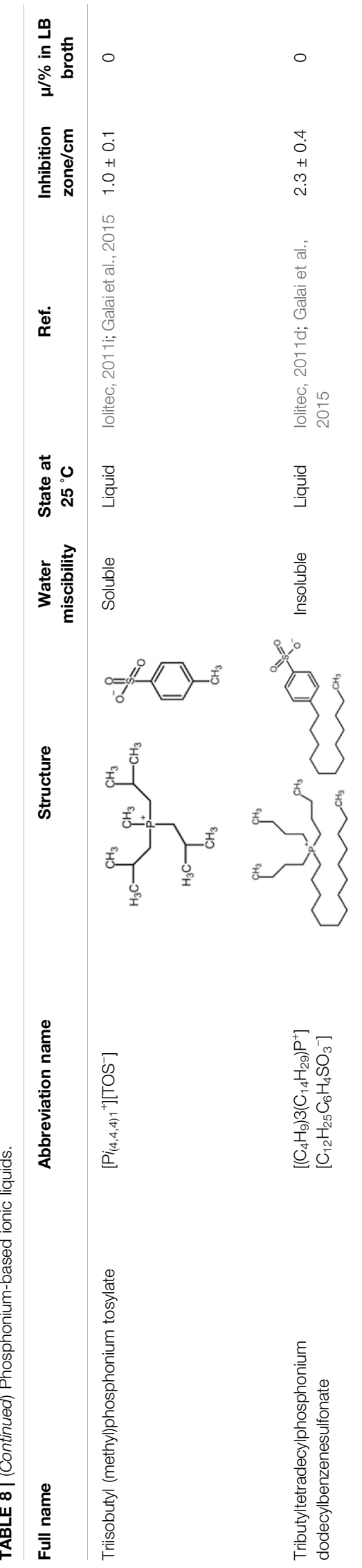

This parameter is shown as a percentage of the growth rate in control cultures without ILs. The specific growth rates in $\%(\mu)$ are reported as a percentage of the growth rate in control cultures grown without ILs $\left(\mu_{0}=0.13 \mathrm{~h}^{-1}\right)$ applying the following equation:

$$
\mu(\%)=\left(\mu^{*} 100\right) / \mu_{0} .
$$

The specific growth rates reported are the mean of triplicate, unless otherwise stated.

\section{RESULTS AND DISCUSSION}

As preliminary information, three types of inhibition were observed in the presence of ILs. The first type corresponds to symmetric inhibition when the IL diffused correctly in the agaragar (Figure 1A). In other cases, the asymmetric inhibition zones offer a variable zone of clearance, rather than a uniform circle around the filter paper, which can be attributed to nonuniform diffusion (Figure 1B) (Rebros et al., 2009). Finally, there are several ILs that do not form an inhibition zone (Figure 1C). The results obtained with the agar diffusion test were compared with the toxicity test in liquid media. As an example, Figure 2 shows the effect of different ILs on the growth of Shewanella sp. The strain was grown in LB broth with and without the respective ILs $(2 \% \mathrm{v} / \mathrm{v})$. The results show that the three ILs displayed $\left[\mathrm{Chol}^{+}\right]\left[\mathrm{H}_{2} \mathrm{PO}_{4}^{-}\right],\left[\mathrm{Bmim}^{+}\right]\left[\mathrm{Cl}^{-}\right]$, and $\left[\mathrm{BMPyr}^{+}\right]\left[\mathrm{TFO}^{-}\right]$are not toxic toward the strain. Moreover, stimulation of bacterial growth (the bacteria utilize the ILs as growth factor) can be obtained. Uninoculated controls with IL are also presented. The means of three replicates are shown with standard deviation error bars.

The effect of the ILs on $\mathrm{pH}$ change was checked in cultures and inoculated controls using a universal indicator $(20 \mathrm{ml})$ added before and after growth. In general, the influence on $\mathrm{pH}$ was small (changes of $<0.5 \mathrm{pH}$ units). On the other hand, as can be expected, the toxicity effect is variable and greatly depends on the chemical structure of each IL. Tables 1-8 include the ILs studied and are organized by type of cation. The structure of the IL and its water solubility, the inhibition zone, and the specific growth rate $\left(\mu, \mathrm{h}^{-1}\right)$ are also presented. The influence of the alkyl substituent of the cation and the type of the cation and anion are systematically analyzed below with the aim to establish toxicitystructure relationships.

\section{Influence of the Alkyl Substituent of the Cation of Ionic Liquid on Toxicity Toward Shewanella sp.}

Although there are no data available in the literature related to the toxicity of ILs toward Shewanella sp., several works have shown that, for other microorganisms, the toxicity is directly correlated with the chain length of the alkyl substituent in the cation (Couling et al., 2006; Luis et al., 2007; Romero et al., 2008; Pretti et al., 2009; Pérez De Los Ríos et al., 2017). The influence of an increasing chain length of R1 or R2 in the imidazolium cation moiety on the cytotoxicity in marine bacteria and two types of 


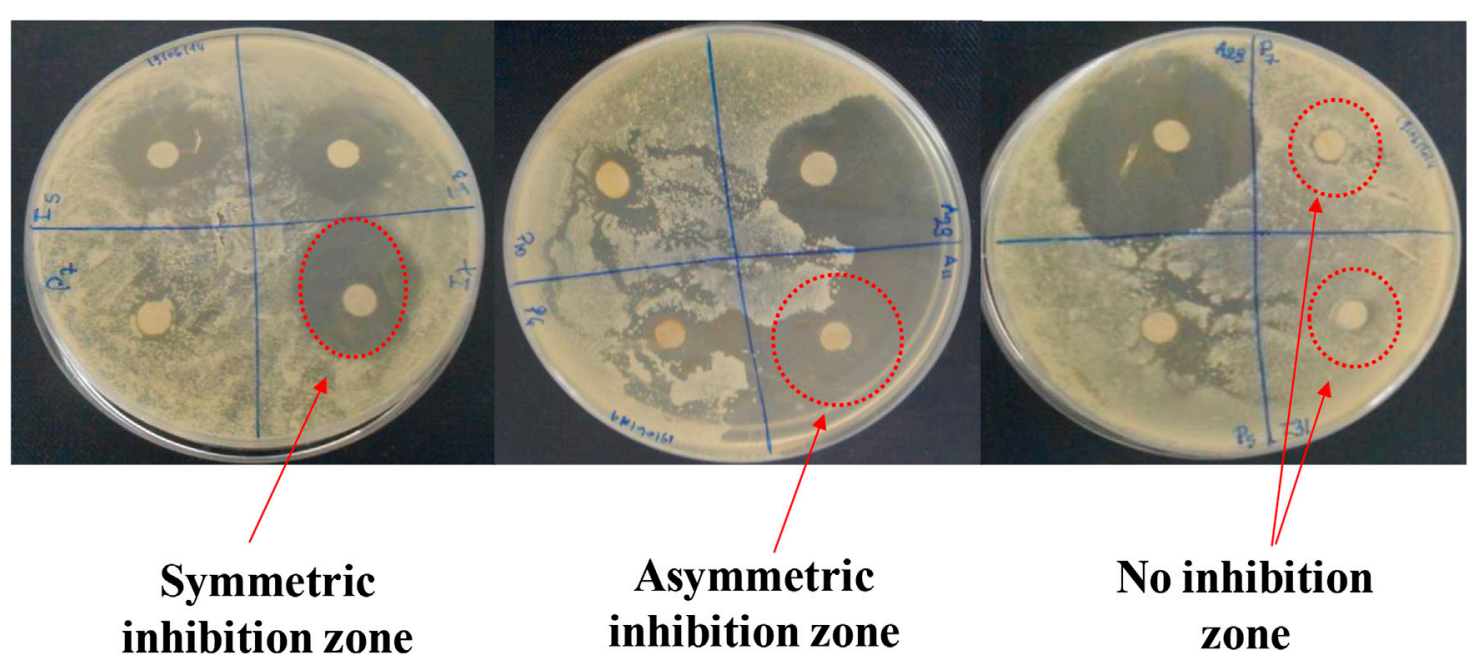

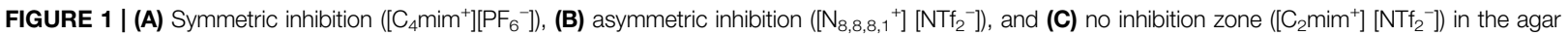
diffusion test.

mammalian cell cultures was also evident in HeLa cells (Stepnowski et al., 2004; Ranke et al., 2007). This effect is currently known as "side-chain effect" (Matzke et al., 2010). For highly lipophilic cations, cytotoxicity does not significantly increase with lipophilicity anymore. It is well known that lipophilicity relationships with biological activity are only linear over a restricted range (Pernak et al., 2003). For Shewanella sp., we also found that behavior. In the case of imidazolium cation combined with dicyanamide, a decrease of the specific growth rate and/or an increase in the inhibition radius was found for the series $\left[\mathrm{Emim}^{+}\right]\left[\mathrm{dca}^{-}\right], \quad\left[\mathrm{Bmim}^{+}\right]\left[\mathrm{dca}^{-}\right], \quad\left[\mathrm{Hmim}^{+}\right]\left[\mathrm{dca}^{-}\right], \quad$ and $\left[\mathrm{Omim}^{+}\right]\left[\mathrm{dca}^{-}\right]$and furthermore from $\left[\mathrm{MOMmim}^{+}\right]\left[\mathrm{dca}^{-}\right]$to $\left[\mathrm{MOEmim}^{+}\right]\left[\mathrm{dca}^{-}\right]$. Increasing inhibition radii as alkyl chain length rises were also obtained in the series $\left[\mathrm{Emim}^{+}\right]\left[\mathrm{NTf}_{2}{ }^{-}\right]$, $\left[\mathrm{Bmim}^{+}\right]\left[\mathrm{NTf}_{2}^{-}\right]$, and $\left[\mathrm{Hmim}^{+}\right]\left[\mathrm{NTf}_{2}^{-}\right]$. Decreasing specific growth rates with the alkyl chain length was observed from $\left[\mathrm{MOMmim}^{+}\right]\left[\mathrm{BF}_{4}^{-}\right]$to $\left[\mathrm{MOEmim}^{+}\right]\left[\mathrm{BF}_{4}^{-}\right]$. For this anion, increasing inhibition radii were found from $\left[\mathrm{Bmim}^{+}\right]\left[\mathrm{BF}_{4}^{-}\right]$to $\left[\mathrm{Omim}^{+}\right]\left[\mathrm{BF}_{4}^{-}\right]$. According to these results, a higher hydrophobic character in ILs would increase the possibility of their interaction with cell membrane phospholipid bilayers and the hydrophobic domains of the membrane proteins, leading to the disruption of the membrane physiological functions and, consequently, to cell death (Stepnowski et al., 2004; Latała et al., 2005; Ranke et al., 2007; Hernández-Fernández et al., 2015).

In some cases, the toxicity of ILs shows a slight decrease with the increase in alkyl chain length, for instance, from $\left[\mathrm{Bmim}^{+}\right]$ $\left[\mathrm{Cl}^{-}\right]$to $\left[\mathrm{Hmim}^{+}\right]\left[\mathrm{Cl}^{-}\right]$(considering the specific growth rate) and from $\left[\mathrm{Bmim}^{+}\right]\left[\mathrm{PF}_{6}^{-}\right]$to $\left[\mathrm{Omim}^{+}\right]\left[\mathrm{PF}_{6}^{-}\right]$(considering both the inhibition radius and the specific growth rate). In this case, an increase in the alkyl chain length also involves a decrease in water media solubility, reducing the effective concentration of the IL in the medium. Besides, the toxic effect of the ILs could depend on the synergy effect of the combined anion and cation and not exclusively on the cation.
As can be observed from Table 1, the inclusion of an oxygen atom in the alkyl substituent of the imidazolium ring can significantly decrease the toxicity of imidazolium-based ILs. In fact, it has been observed that $\left[\mathrm{HOPmim}^{+}\right]\left[\mathrm{Cl}^{-}\right](\mu=73.5 \%)$ displayed much lower toxic effects than $\left[\mathrm{Bmim}^{+}\right]\left[\mathrm{Cl}^{-}\right](\mu=$ $30.5 \%)$ and also the toxic effect of $\left[\mathrm{MOEmim}^{+}\right]\left[\mathrm{BF}_{4}^{-}\right](\mu=$ $34.7 \%)$ on Shewanella was lower than that of $[\mathrm{Bmim}]\left[\mathrm{BF}_{4}^{-}\right]$ $(\mu=0 \%)$. This behavior is in agreement with the work by Álvarez-Guerra and Irabien (Alvarez-Guerra and Irabien, 2011), who reported that the presence of oxygenated groups in the structure of cations can lead to a decrease in the ecotoxicity of the IL. In this sense, the presence of oxygen makes the IL more hydrophilic, and therefore, less toxic. On the contrary, the toxicity of $\left[\mathrm{Bmim}^{+}\right]\left[\mathrm{NO}_{3}{ }^{-}\right]$was higher than the toxicity of [HOPmim] $\left[\mathrm{NO}_{3}{ }^{-}\right]$. The higher water solubility of $\left[\mathrm{HOPmim}{ }^{+}\right]\left[\mathrm{NO}_{3}{ }^{-}\right]$and consequently the higher effective concentration in water medium might explain this fact.

\section{Effect of the Ionic Liquid Cation on Toxicity Toward Shewanella sp.}

In order to study the effect of the cation, ILs with the same anion and different cation will be compared. This is the best way to systematically study the toxicity of ILs; however, it is important to point out that toxicity synergy effects could occur between anions and cations, and consequently the sequence of toxicity could be modified for different anion families. In this case, it is difficult to separate individual anion and cation contributions to toxicity. In general and in terms of cation toxicity for other microorganisms, ILs containing aromatic cations, such as imidazolium and pyridinium cations, have shown higher levels of toxicity in comparison to those including nonaromatic cations like pyrrolidinium. A higher hydrophobic character of aromatic cations could increase the possibility of interaction with the cell membrane (Stepnowski et al., 2004; Latała et al., 2005; Ranke et al., 2007). Furthermore, the planarity of the cation 

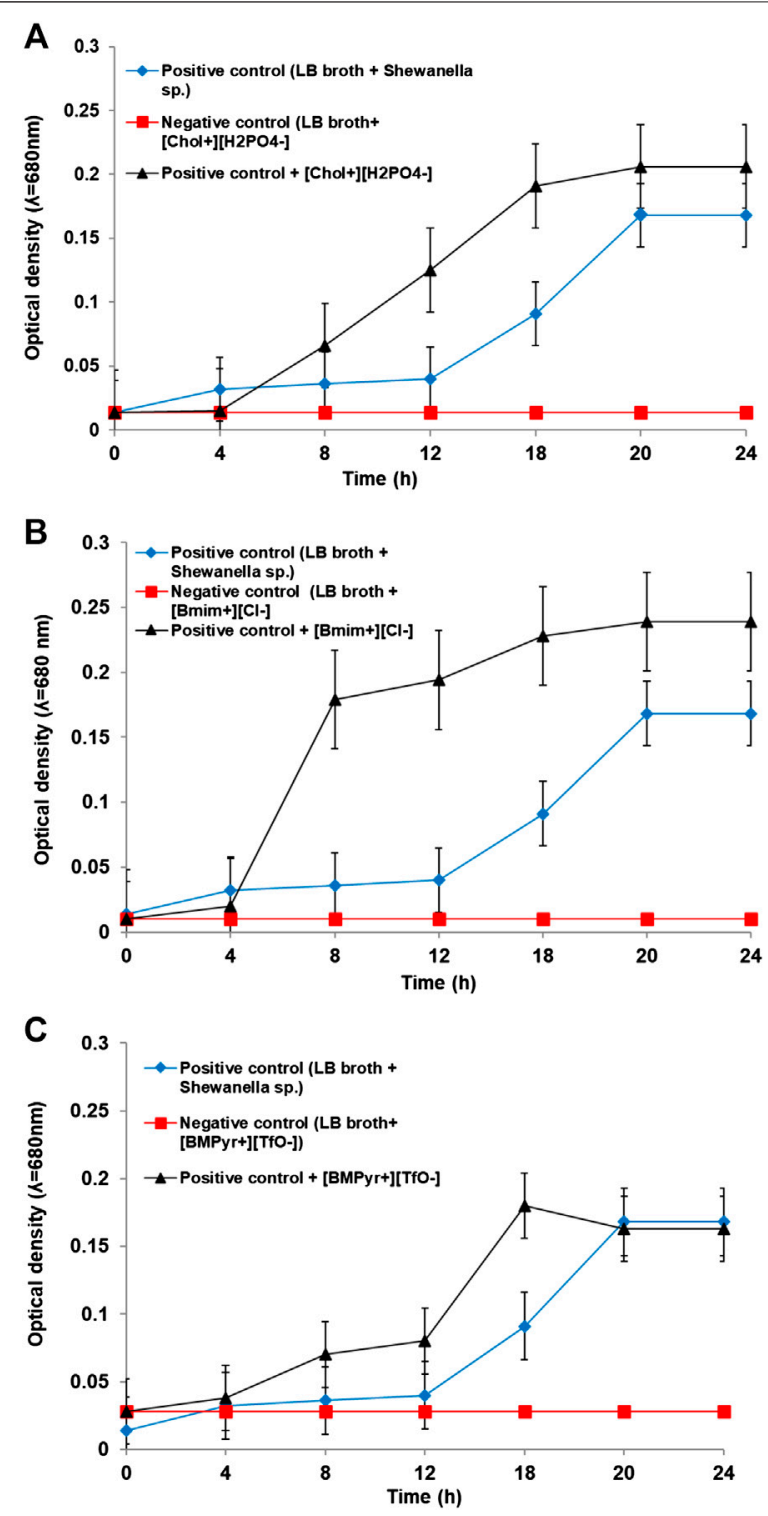

FIGURE 2 | (A) Growth profile of Shewanella sp. in LB broth. (-) Negative control (LB+[Chol $\left.\left.{ }^{+}\right]\left[\mathrm{H}_{2} \mathrm{PO}_{4}{ }^{-}\right] 2 \% \mathrm{v} / \mathrm{V}\right)$. ( $\bullet$ ) Positive control LB + Shewanella sp. ( $\mathbf{\Delta})$ Positive control $+\left[\mathrm{Chol}^{+}\right]\left[\mathrm{H}_{2} \mathrm{PO}_{4}^{-}\right]$. (B) Growth profile of Shewanella sp. in LB broth. (-) Negative control $\left(\mathrm{LB}+\left[\mathrm{Bmim}^{+}\right]\left[\mathrm{Cl}{ }^{-}\right] 2 \% \mathrm{v} / \mathrm{V}\right)$. ( $\bullet$ ) Positive control LB + Shewanella sp. (4) Positive control $+\left[\mathrm{Bmim}^{+}\right]\left[\mathrm{Cl}^{-}\right]$. (C) Growth profile of Shewanella sp. in LB broth. ( $\bullet$ ) Negative control (LB+ [BMPyr $\left.\left.{ }^{+}\right] \mathrm{TFO}^{-}\right]$ $2 \% \mathrm{v} / \mathrm{v})$. ( ) Positive control LB + Shewanella sp. (ム) Positive control $+\left[\mathrm{BMPyr}^{+}\right][\mathrm{TFO}-]$.

ring in imidazolium and pyridinium appeared to be also a relevant parameter for increasing IL toxicity, as reported in (Viboud et al., 2012). This fact could be due to the lower steric hindrance of the aromatic cation, which may favor the interactions with the lipid membrane to a greater extent.

For Shewanella sp., higher toxicity was found for imidazolium cations compared with pyrrolidinium cations in the case of $\left[\mathrm{Bmim}^{+}\right]\left[\mathrm{PF}_{6}^{-}\right]$vs. $\left[\mathrm{BMPyr}^{+}\right]\left[\mathrm{PF}_{6}^{-}\right]$(inhibition radius 2.9 vs. $0.8 \mathrm{~cm}$, respectively), $\left[\mathrm{Bmim}^{+}\right]\left[\mathrm{dca}^{-}\right]$vs. $\left[\mathrm{BMPyr}^{+}\right]\left[\mathrm{dca}^{-}\right]$, and
$[\mathrm{Bmim}]\left[\mathrm{NTf}_{2}{ }^{-}\right]$vs. $\left[\mathrm{BMPyr}^{+}\right]\left[\mathrm{NTf}_{2}{ }^{-}\right]$. No significant differences were found between $\left[\mathrm{Emim}^{+}\right]\left[\mathrm{NTf}_{2}^{-}\right]$and $\left[\mathrm{EMPyr}^{+}\right]\left[\mathrm{NTf}_{2}^{-}\right]$. On the contrary, the toxicity of $\left[\mathrm{Bmim}^{+}\right]\left[\mathrm{NTf}_{2}{ }^{-}\right]$was lower than the toxicity of $\left[\mathrm{BMPyr}^{+}\right]\left[\mathrm{NTf}_{2}^{-}\right]$. It is also important to remark the higher toxicity observed for $\left[\mathrm{Bmim}^{+}\right]\left[\mathrm{BF}_{4}{ }^{-}\right]$compared to the toxicity of $\left[\mathrm{BDImim}^{+}\right]\left[\mathrm{BF}_{4}^{-}\right]$. The inclusion of the methyl substituent in the $\mathrm{R} 2$ position of the imidazolium ring could reduce the acid proton in 2, so lowering the toxicity of the IL.

The effect of pyridinium cations was studied by comparison of imidazolium-based ILs with equal alkyl chain length and anions. In all cases, a higher toxicity was found for the imidazolium cation with respect to the pyridinium cation by comparing $\left[\mathrm{Bmim}^{-}\right]\left[\mathrm{BF}_{4}^{+}\right]$vs. $\left[\mathrm{BMPy}^{+}\right]\left[\mathrm{BF}_{4}^{-}\right], \quad\left[\mathrm{Bmim}^{+}\right]\left[\mathrm{dca}^{-}\right]$vs. $\left[\mathrm{BMPy}^{+}\right]\left[\mathrm{dca}^{-}\right]$, and $\left[\mathrm{Omim}^{+}\right]\left[\mathrm{dca}^{-}\right]$vs. $\left[\mathrm{OMPy}^{+}\right]\left[\mathrm{dca}^{-}\right]$. Regarding the piperidinium-based IL studied, $\left[\mathrm{BMPi}^{+}\right]\left[\mathrm{NTf}_{2}{ }^{-}\right]$, there were no significant differences with their homologous imidazolium and pyrrolidinium ones $\left(\left[\mathrm{Bmim}^{+}\right]\left[\mathrm{NTf}_{2}^{-}\right]\right.$vs. $\left[\mathrm{BMPyr}^{+}\right]\left[\mathrm{NTf}_{2}{ }^{-}\right]$. The morpholinium cation in $\left[\mathrm{EMMOR}^{+}\right]$ $\left[\mathrm{dca}^{-}\right]$can be compared with $\left[\mathrm{Emin}^{+}\right]\left[\mathrm{dca}^{-}\right]$. In both cases, the inhibition radius was zero and the growth rate was higher for the imidazolium-based IL. Matzke et al. (2008) studied the morpholinium compound founding that it only exhibited a moderate effect on the aquatic plant Lemna minor and the algae Scenedesmus vacuolatus. The oxazolinium cation in $\left[\mathrm{Moxa}^{+}\right]\left[\mathrm{MeSO}_{4}^{-}\right]$can be compared with the pyridinium cation in $\left[\mathrm{MPy}^{+}\right]\left[\mathrm{MeSO}_{4}^{-}\right]$; in this case, the toxicity of the pyridinium cation was lower than that of the $\left[\mathrm{Moxa}^{+}\right]$cation, considering both the inhibition radius ( 0 vs. $1.1 \mathrm{~cm}$, respectively) and the growth rate (170.7 vs. $25.4 \%$, respectively).

For ILs based on the ammonium cation, different toxicity values were found depending on the alkyl chain length of the cation and the type of the anion. The toxicity values ranged from the highest toxicity for C1EG, C1EG1, and $\left[\mathrm{N}_{8881}{ }^{+}\right]\left[\mathrm{Cl}^{-}\right]$ (inhibition radius of $3 \mathrm{~cm}$ and $0 \%$ growth rate) to the lowest toxicity for $\left[\mathrm{N}_{8881}{ }^{+}\right]\left[\mathrm{CF}_{3} \mathrm{SO}_{3}{ }^{-}\right](1.4 \mathrm{~cm}$ of inhibition radius and $179 \%$ of growth rate). Wood and Stephens (2010) found that quaternary ammonium salts were generally toxic to $E$. coli. However, it was evidenced that decreasing alkyl chain lengths reduced the toxicity. Our experiment reveals that quaternary ammonium salts are generally toxic, maybe due to their high lipophilic character. However, $\left[\mathrm{Chol}^{+}\right]\left[\mathrm{H}_{2} \mathrm{PO}_{4}{ }^{-}\right]$and [221PG] (TEGO ${ }^{\circledR}$-IL-P9) displayed low toxicity toward the strain tested, not inhibiting the bacterial growth in the agar diffusion test. In these cases, the cation contains heteroatoms and short alkyl chains.

Phosphonium-based ILs have been less frequently studied in comparison to other groups despite their high industrial interest (for example, in biotransformation processes such as xenobiotics degradation) (Cieniecka-Rosłonkiewicz et al., 2005). The toxicity results obtained for the phosphonium family suggest that long alkyl chains promote higher toxic effects toward the bacterium (Matzke et al., 2010). The same result was found by Stolte et al. (2008) for phosphonium cations with longer chains (C12, C16, and C18), with a strong inhibitory potential to the used inoculum. The high toxicity of phosphonium halides against Vibrio fischeri was also proved (Couling et al., 2006). However, there are possibilities to decrease the antimicrobial activity using long 
alkyl chains, e.g., phosphonium based on alkyl chains of 8 and 14 carbons conjugated with the chloride anion. The exchange of the halide by other anions resulted in a loss of antimicrobial activity (Cieniecka-Rosłonkiewicz et al., 2005). In this study, we found that 9 out of 12 phosphonium ILs were very toxic toward Shewanella sp. (large radii of inhibition zone and $\mu$ of $0 \%$ for the bacterial growth in liquid phase). In the case of phosphonium-based IL, the toxicity values ranged from $5.5 \mathrm{~cm}$ of inhibition radius and $0 \%$ growth rate $\left(\left[\mathrm{P}_{14,6,6,6}{ }^{+}\right]\left[\mathrm{Br}^{-}\right]\right)$to $1.8 \mathrm{~cm}$ of inhibition rate and $108.3 \%$ of growth rate $\left(\left[\mathrm{P}_{14,6,6,6}{ }^{+}\right]\right.$ $\left.\left[\mathrm{BF}_{4}^{-}\right]\right)$. For sulfonium-based ILs, only one compound was assayed, offering high toxicity since no growth of Shewanella was observed and the inhibition radius was $1.5 \mathrm{~cm}$.

\section{Effect of the Ionic Liquid Anion on Toxicity toward Shewanella sp.}

The effect of the anion composition on the toxicity was analyzed by comparing ILs with different anions and the same cation. As commented above, synergy effects between anion and cation can occur, which makes it difficult to completely isolate individual anion and cation contributions. Several authors have reported that the toxicity is directly correlated to the cation nature, while the anion seems to modulate the toxicity to some extent and in specific cases (Ranke et al., 2004; Couling et al., 2006; Luis et al., 2007; Romero et al., 2008; Pretti et al., 2009). We observed this behavior in several ILs in which the toxicity values were similar when sharing the same cation but containing different anions. For example, for the $\left[\mathrm{Bmim}^{+}\right]$family, zero growth rate was obtained for the anions $\left[\mathrm{PF}_{6}^{-}\right],\left[\mathrm{dca}^{-}\right],\left[\mathrm{SCN}^{-}\right],\left[\mathrm{MeCOO}_{2}{ }^{-}\right],\left[\mathrm{NTf}_{2}^{-}\right]$, $\left[\mathrm{HSO}_{4}^{-}\right], \quad\left[\mathrm{CH}_{3} \mathrm{COO}^{-}\right]$, and $\left[\mathrm{BF}_{4}^{-}\right]$with inhibition radii ranging from 2.9 to $0.7 \mathrm{~cm}$. Stolte et al. (2007a) showed that anions with lipophilicity or susceptible to hydrolysis could offer partially drastic effects. In this group, $\left[\mathrm{PF}_{6}^{-}\right]$could be included since it can be hydrolyzed in the presence of water, consequently delivering HF to the medium; $\left[\mathrm{NTf}_{2}{ }^{-}\right]$could be also included due to its hydrophobicity. Growth rate values higher than zero were obtained for $\left[\mathrm{TFES}^{-}\right],\left[\mathrm{Cl}^{-}\right],\left[\mathrm{CH}_{2} \mathrm{OHCOO}^{-}\right]$, and $\left[\mathrm{NO}_{3}{ }^{-}\right](13.6$, $30.5,30$, and 102.8 , respectively). The $\left[\mathrm{Cl}^{-}\right]$anion yielded low toxicity when combined with other imidazolium cations such as [HOPmim $\left.{ }^{-}\right]$and $\left[\mathrm{Hmim}^{-}\right]$. Wood et al. (2011) tested the toxicity of imidazolium cations combined with halides $\left(\left[\mathrm{Cl}^{-}\right]\left[\mathrm{Br}^{-}\right]\right)$ toward E. coli. The $\left[\mathrm{Emim}^{+}\right]$and $\left[\mathrm{Bmim}^{+}\right]$chlorides and bromides did not produce inhibition zones in the agar diffusion test; however, inhibition zones were observed when the alkyl chain was increased up to six and eight carbons. Shortchained imidazolium salts [EMIM] and [BMIM] with a chloride anion proved weak antimicrobial activity (Euczak et al., 2010). Therefore, for longer alkyl chain derivatives, the toxicity of the anion can be neglected in comparison to the effects caused by the corresponding cation. On the other hand, for $\left[\mathrm{Cl}^{-}\right]$combined with pyrrolidinium $\left(\left[\mathrm{BMPyr}^{+}\right]\right)$and ammonium $\left(\left[\mathrm{N}_{8,8,8,1}{ }^{+}\right]\right)$, high toxicity was found. Cornmell et al. (2008) reported that the IL $\left[\mathrm{N}_{1,8,8,8}{ }^{+}\right]\left[\mathrm{Cl}^{-}\right]$did not allow any growth for E. coli. The $\left[\mathrm{BF}_{4}{ }^{-}\right]$anion gave rate growth values over $30 \%$ for $\left[\mathrm{Emim}^{+}\right]$ [MOEmim $\left.{ }^{+}\right]$, over $100 \%$ for $\left[\mathrm{P}_{6,6,6,14}{ }^{+}\right]$, and even over $200 \%$ for $\left[\mathrm{MOMmim}^{+}\right]$and $\left[\mathrm{BMPy}^{+}\right]$; however, nongrowth of Shewanella was observed in $\left[\mathrm{Bmim}^{+}\right]\left[\mathrm{BF}_{4}^{-}\right]$. For other frequent anions such as $\left[\mathrm{dca}^{-}\right],\left[\mathrm{PF}_{6}^{-}\right]$, and $\left[\mathrm{NTf}_{2}^{-}\right]$, a wide variety of toxicity values was found, depending on the paired cation. For instance $\left[\mathrm{dca}^{-}\right]$ combined with $\left[\mathrm{Bmim}^{+}\right],\left[\mathrm{Emim}^{+}\right],\left[\mathrm{Hmim}^{+}\right],\left[\mathrm{MOMmim}^{+}\right]$, $\left[\mathrm{MOEmim}^{+}\right],\left[\mathrm{Omim}^{+}\right],\left[\mathrm{BMPy}^{+}\right],\left[\mathrm{BMPyr}^{+}\right]$, or $\left[\mathrm{P}_{6,6,6,14}{ }^{+}\right]$ yielded growth rates from 0 to $155 \%$. This fact could be attributed to the dependency of the toxicity values on the IL cation and the possible synergy toxicity effects between the cation and anion.

\section{Choosing the Less Toxic lonic Liquids for Shewanella sp. Applications}

Two general possibilities for the joint application of ILs and Shewanella sp. in chemical processes are 1) the use of ILs as reaction media in biotechnological processes or 2) the use of ILs as extractants in biphasic systems with Shewanella sp. in an aqueous phase. For the first scenario, the key aspect is to find an IL compatible with this bacterium. The results obtained in this study in terms of biocompatibility have been obtained from a wide range of compounds, but they can also help us to qualitatively predict the toxicity of other nonanalyzed ILs. From this work, we can know that several ILs could serve as a medium for Shewanella sp. or could be used in different applications such as microbial fuel cells, in which Shewanella sp. act as biocatalysts and ILs are used for membrane preparation. Between the biocompatible ILs, we have found the following: $\left[\mathrm{Hmim}^{+}\right]\left[\mathrm{Cl}^{-}\right], \quad\left[\mathrm{MOMmim}^{+}\right]\left[\mathrm{BF}_{4}^{-}\right], \quad\left[\mathrm{MOMmim}^{+}\right]\left[\mathrm{dca}^{-}\right]$, $\left[\mathrm{BMPy}^{+}\right]\left[\mathrm{BF}_{4}^{-}\right]$, and $\left[\mathrm{EPy}^{+}\right]\left[\mathrm{ETSO}_{4}^{-}\right]$. These selected ILs have a growth rate higher than $150 \%$ and an inhibition radius equal to zero. It is important to remark that in all cases these ILs were water-soluble, which relates the idea of water solubility to biocompatibility. This is highlighted by the fact that 19 out of 29 insoluble ILs allowed no growth, while only 17 out of 40 watersoluble ILs showed no growth for Shewanella sp. Furthermore, only two water-insoluble ILs provided growth rates over $100 \%$, $\left[\mathrm{N}_{8,8,8,1}{ }^{+}\right]\left[\mathrm{CF}_{3} \mathrm{SO}_{3}{ }^{-}\right]$and $\left[\mathrm{P}_{6,6,6,14}{ }^{+}\right]\left[\mathrm{BF}_{4}{ }^{-}\right]$, and in both cases, the inhibition radius was higher than $1.4 \mathrm{~cm}$.

It is important to note that it is hard to find conventional organic solvents that extract polar compounds from the water with high efficiency since they would need to be water-insoluble and polar, two properties barely possible in conventional organic solvents. These limitations can be overcome in the case of using ILs as extractant medium from water solutions. Furthermore, the ILs would have to be biocompatible with Shewanella sp. In this case, the two ILs, $\left[\mathrm{N}_{8,8,8,1}{ }^{+}\right]\left[\mathrm{CF}_{3} \mathrm{SO}_{3}{ }^{-}\right]$and $\left[\mathrm{P}_{6,6,6,14}{ }^{+}\right]\left[\mathrm{BF}_{4}{ }^{-}\right]$, could meet both conditions.

\section{Mechanisms of Ionic Liquid Toxicity}

Relatively, few mechanisms have been suggested to explain the toxicity of ILs toward marine bacteria, but membrane disruption is considered the most common. ILs at concentrations several orders of magnitude higher than those used in our study have been shown to disrupt synthetic membranes (Sena et al., 2010). In aquatic systems, the side-chain effect could be observed even with the shorter side chains, e.g., IM12 (1-ethyl-3-methylimidazolium) and IM14 (1-butyl-3-methyl-imidazolium), which means that the EC50 values for IM12 are higher than 
for IM14 (Stolte et al., 2007a; Stolte et al., 2007b). Our results support the membrane disruption mechanism by toxic ILs since, in general, increasing toxicity is observed with increasing IL hydrophobicity and alkyl chain length in the cation (which also contributes to IL hydrophobicity). Furthermore, the inclusion of a heteroatom such as oxygen leads to reducing hydrophobicity and thus toxicity. Nevertheless, other molecular mechanisms cannot be excluded when explaining the toxicity of ILs.

\section{CONCLUSIONS}

This work assesses the toxicity of a high number of ILs toward Shewanella sp. in order to analyze their biocompatibility and possible joint application for bioprocess implementation. We observed that the adequate combination of cations and anions can make the whole molecule safe for alive bacterial cells in bioprocess devices. Different and wide ion combinations are possible, by selecting cation-anion combinations suitable to specific applications, which highlights the necessity of screening IL toxicity toward the design of biocompatible compounds.

The results obtained allowed establishing several toxicitystructure relationships. According to the results obtained, the immiscibility of ILs in water has an important effect on the toxicity behavior of the ILs since $66 \%$ of the water-immiscible ILs tested were highly toxic, whereas only $42 \%$ of immiscible ILs were highly toxic. Furthermore, it was observed that the length of the alkyl chain of the cation presented an important impact on IL toxicity. As a general trend, an increase in the alkyl chain length, which involves an increase in the hydrophobicity, contributes to rising IL toxicity.

It was also determined that several ILs could be used as reaction media in the presence of Shewanella sp. based on their biocompatibility and water miscibility, specifically $\left[\mathrm{Hmim}^{+}\right]\left[\mathrm{Cl}^{-}\right], \quad\left[\mathrm{MOMmim}^{+}\right]\left[\mathrm{BF}_{4}^{-}\right], \quad\left[\mathrm{MOMmim}^{+}\right]\left[\mathrm{dca}^{-}\right]$, $\left[\mathrm{BMPy}^{+}\right]\left[\mathrm{BF}_{4}^{-}\right]$, and $\left[\mathrm{EPy}^{+}\right]\left[\mathrm{ETSO}_{4}^{-}\right]$. In the case of waterinsoluble ILs, $\left[\mathrm{N}_{8,8,8,1}{ }^{+}\right]\left[\mathrm{CF}_{3} \mathrm{SO}_{3}^{-}\right]$and $\left[\mathrm{P}_{6,6,6,14}{ }^{+}\right]\left[\mathrm{BF}_{4}^{-}\right]$ showed to be suitable ILs for their use as extractant medium

\section{REFERENCES}

Åkerstedt, J., Gorlov, M., and Kloo, L. (2013). Room-temperature synthesis of the $\mathrm{Bi5}[\mathrm{GaCl} 4] 3$ salt from three different classes of ionic liquids. J. Cluster Sci. 24, 157-164. doi:10.1007/s10876-012-0526-3

Alvarez-Guerra, M., and Irabien, A. (2011). Design of ionic liquids: an ecotoxicity (Vibrio fischeri) discrimination approach. Green Chem. 13, 1507-1516. doi:10. 1039/c0gc00921k

Balducci, A., Henderson, W. A., Mastragostino, M., Passerini, S., Simon, P., and Soavi, F. (2005). Cycling stability of a hybrid activated carbon//poly(3methylthiophene) supercapacitor with N-butyl-N-methylpyrrolidinium bis(trifluoromethanesulfonyl) imide ionic liquid as electrolyte. Electrochim. Acta. 50, 2233-2237. doi:10.1016/j.electacta.2004.10.006

Balouiri, M., Sadiki, M., and Ibnsouda, S. K. (2016). Methods for in vitro evaluating antimicrobial activity: a review. J. Pharm. Anal. 6, 71-79. doi:10.1016/j.jpha. 2015.11.005

Bandrés, I., Giner, B., Gascón, I., Castro, M., and Lafuente, C. (2008). Physicochemical characterization of n-Butyl-3-methylpyridinium dicyanamide ionic liquid. J. Phys. Chem. B. 39, 12461-12467. doi:10.1021/jp805816x. for Shewanella sp. This work demonstrates the potential combination of IL technology and Shewanella sp. The results of this study are encouraging and also suggest that new fields could be explored with Shewanella sp. and IL materials.

\section{DATA AVAILABILITY STATEMENT}

The original contributions presented in the study are included in the article/supplementary material; further inquiries can be directed to the corresponding authors.

\section{AUTHOR CONTRIBUTIONS}

HK: Data curation, formal analysis, investigation, methodology, writing-original draft. AR: conceptualization, resources, funding acquisition, supervision, writing-review and editing. MS and VO: data curation, formal analysis, writing-original draft, writing-review and editing. MK: funding acquisition, supervision. $\mathrm{JH}$ : writing-review and editing. $\mathrm{FH}$ : conceptualization, funding acquisition, project administration, resources, supervision, writing-original draft, writing-review and editing.

\section{FUNDING}

This work has been funded by the Spanish Ministry of Economy and Competitiveness (MINECO) (Grant number: RTI2018-099011-B-I00) and Séneca Foundation (Grant number: 20957/PI/18).

\section{ACKNOWLEDGMENTS}

H. Kebaili thanks Erasmus Mundus Program for the fellowship for students' exchange received.

Barisci, J. N., Wallace, G. G., MacFarlane, D. R., and Baughman, R. H. (2004) Investigation of ionic liquids as electrolytes for carbon nanotube electrodes. Electrochem. Commun. 6, 22-27. doi:10.1016/j.elecom.2003.09.015

Benito, J., García-Mardones, M., Pérez-Gregorio, V., Gascón, I., and Lafuente, C. (2014). Physicochemical study of n-ethylpyridinium bis(trifluoromethylsulfonyl) imide ionic liquid. J. Solut. Chem. 43, 696-710. doi:10.1007/s10953-014-0156-5

Carda-Broch, S., Berthod, A., and Armstrong, D. W. (2003). Solvent properties of the 1-butyl-3-methylimidazolium hexafluorophosphate ionic liquid. Anal. Bioanal. Chem. 375, 191-199. doi:10.1007/s00216-002-1684-1

Cieniecka-Rosłonkiewicz, A., Pernak, J., Kubis-Feder, J., Ramani, A., Robertson, A. J., and Seddon, K. R. (2005). Synthesis, anti-microbial activities and antielectrostatic properties of phosphonium-based ionic liquids. Green Chem. 7, 855-862. doi:10.1039/b508499g

Clinical and Laboratory Standards Institute (2015). M02-A12 performance standards for antimicrobial disk susceptibility tests; approved standard-twelfth edition. Wayne, PA: Clinical and Laboratory Standards Institute.

Cornmell, R. J., Winder, C. L., Tiddy, G. J. T., Goodacre, R., and Stephens, G. (2008). Accumulation of ionic liquids in Escherichia coli cells. Green Chem. 10, 836-884. doi:10.1039/b807214k 
Couling, D. J., Bernot, R. J., Docherty, K. M., Dixon, J. N. K., and Maginn, E. J. (2006). Assessing the factors responsible for ionic liquid toxicity to aquatic organisms via quantitative structure-property relationship modeling. Green Chem. 8, 82-90. doi:10.1039/b511333d

Cumicheo, M. C., Nobre, L. C. S., Santos, A. F., Lampreia, I. M. S., Santos, M. S. C. S., Santos, F. J. V., et al. (2015). Thermophysical properties of 1-Butyl-1-methylpyrrolidinium dicyanamide $+\mathrm{H} 2 \mathrm{O}$ mixtures. J. Chem. Eng. Data. 60, 3766-3775. doi:10.1021/acs.jced.5b00944

de los Ríos, A. P., van Rantwijk, F., and Sheldon, R. A. (2012). Effective resolution of 1-phenyl ethanol by Candida Antarctica lipase B catalysed acylation with vinyl acetate in protic ionic liquids (PILs). Green Chem. 14, 1584-1588. doi:10.1039/ c2gc35196j

Derby, H. A., and Hammer, B. W. (1931). Bacteriology of butter IV. Bacteriological studies on surface taint butter. Iowa Agric. Home Econ. Exp. Stn. Res. Bull. 145, 387-416.

Dharaskar, S. A., Varma, M. N., Shende, D. Z., Yoo, C. K., and Wasewar, K. L. (2013). Synthesis, characterization and application of 1-butyl-3 methylimidazolium chloride as green material for extractive desulfurization of liquid fuel. Sci. World J. 2013, 395274. doi:10.1155/2013/395274

Dharaskar, S. A., Wasewar, K. L., Varma, M. N., and Shende, D. Z. (2016a). Synthesis, characterization, and application of 1-butyl-3-methylimidazolium thiocyanate for extractive desulfurization of liquid fuel. Environ. Sci. Pollut. Res. 23, 9284-9294. doi:10.1007/s11356-015-4945-1

Dharaskar, S. A., Wasewar, K. L., Varma, M. N., Shende, D. Z., and Yoo, C. K. (2016b). Synthesis, characterization and application of 1-butyl-3methylimidazolium tetrafluoroborate for extractive desulfurization of liquid fuel. Arab. J. Chem. 9, 578-587. doi:10.1016/j.arabjc.2013.09.034

Ding, J., Zhou, D., Spinks, G., Wallace, G., Forsyth, S., Forsyth, M., et al. (2003). Use of ionic liquids as electrolytes in electromechanical actuator systems based on inherently conducting polymers. Chem. Mater. 15, 2392-2398. doi:10.1021/ cm020918k

Dupont, J., Fonseca, G. S., Umpierre, A. P., Fichtner, P. F. P., and Teixeira, S. R. (2002). Transition-metal nanoparticles in imidazolium ionic liquids: recycable catalysts for biphasic hydrogenation reactions. J. Am. Chem. Soc. 124, 4228-4229. doi:10.1021/ja025818u

Earle, M., Wasserscheid, P., Schulz, P., Olivier-Bourbigou, H., Favre, F., Vaultier, M., et al. (2008). "Organic synthesis," in Ionic liquids in synthesis. Weinheim, Germany: Wiley-VCH Verlag GmbH \& Co. KGaA, 265-568. doi:10.1002/ 9783527621194.ch5

Eastoe, J., Gold, S., Rogers, S. E., Paul, A., Welton, T., Heenan, R. K., et al. (2005). Ionic liquid-in-oil microemulsions. J. Am. Chem. Soc. 127, 7302-7303. doi:10. 1021/ja051155f

El Abedin, S. Z., and Endres, F. (2007). Ionic liquids: the link to high-temperature molten salts? Acc. Chem. Res. 40, 1106-1113. doi:10.1021/ar700049w

Endres, F. (2002). Ionic liquids: solvents for the electrodeposition of metals and semiconductors. ChemPhysChem. 3, 145-154. doi:10.1002/14397641(20020215)3:2<144::aid-cphc144>3.0.co;2-\#

Fadeeva, T. A., Husson, P., Devine, J. A., Costa Gomes, M. F., Greenbaum, S. G., and Castner, E. W. (2015). Interactions between water and 1-butyl-1methylpyrrolidinium ionic liquids. J. Chem. Phys. 143, 064503. doi:10.1063/ 1.4928065

Freire, M. G., Santos, L. M. N. B. F., Fernandes, A. M., Coutinho, J. A. P., and Marrucho, I. M. (2007). An overview of the mutual solubilities of waterimidazolium-based ionic liquids systems. Fluid Phase Equil. 261, 449-454. doi:10.1016/j.fluid.2007.07.033

Galai, S., De Los Ríos, A. P., Hernández-Fernández, F. J., Haj Kacem, S., and Tomas-Alonso, F. (2015). Over-activity and stability of laccase using ionic liquids: screening and application in dye decolorization. RSC Adv. 5, 16173-16189. doi:10.1039/c4ra07351g

Gorlov, M., and Kloo, L. (2008). Ionic liquid electrolytes for dye-sensitized solar cells. J. Chem. Soc., Dalton Trans. 2655-2666. doi:10.1039/b716419j

Haddleton, D. M., Welton, T., and Carmichael, A. J. (2008). "Polymer synthesis in ionic liquids," in Ionic liquids in synthesis. Weinheim, Germany: Wiley-VCH Verlag GmbH \& Co. KGaA, 619-640. doi:10.1002/9783527621194.ch7

Hau, H. H., and Gralnick, J. A. (2007). Ecology and biotechnology of the genus shewanella. Annu. Rev. Microbiol. 61, 237-258. doi:10.1146/annurev.micro.61. 080706.093257
Heatley, N. G. (1944). A method for the assay of penicillin. Biochem. J. 38, 61-65. doi:10.1042/bj0380061

Hernández, F. J., de los Ríos, A. P., Gómez, D., Rubio, M., and Víllora, G. (2006). A new recirculating enzymatic membrane reactor for ester synthesis in ionic liquid/supercritical carbon dioxide biphasic systems. Appl. Catal. B Environ. 67, 121-126. doi:10.1016/j.apcatb.2006.04.009

Hernández-Fernández, F. J., Bayo, J., Pérez de los Ríos, A., Vicente, M. A., Bernal, F. J., and Quesada-Medina, J. (2015). Discovering less toxic ionic liquids by using the Microtox ${ }^{\circledR}$ toxicity test. Ecotoxicol. Environ. Saf. 116, 29-33. doi:10.1016/j. ecoenv.2015.02.034

Iolitec (2010). Safety data sheet IoLiLyte T2EG.

Iolitec (2011a). Technical data sheet 1-Butyl-1-methylpyrrolidinium bis(trifluoromethylsulfonyl)imide.

Iolitec (2011b). Technical data sheet 1-Butyl-1-methylpyrrolidinium dicyanamide.

Iolitec (2011c). Technical data sheet 1-Butyl-1-methylpyrrolidinium hexafluorophosphate.

Iolitec (2011d). Technical data sheet tributyltetradecylphosphonium dodecylbenzenefulfonate.

Iolitec (2011e). Technical data sheet trihexyltetradecylphosphonium bis(trifluoromethylsulfonyl)imide.

Iolitec (2011f). Technical data sheet trihexyltetradecylphosphonium bromide. Iolitec (2011g). Technical data sheet trihexyltetradecylphosphonium chloride. Iolitec $(2011 \mathrm{~h})$. Technical data sheet trihexyltetradecylphosphonium dicyanamide. Iolitec (2011i). Technical data sheet triisobutylmethylphosphonium tosylate.

Iolitec (2012a). Technical data sheet 1-Butyl-1-methylpiperidinium bis(trifluoromethylsulfonyl)imide.

Iolitec (2012b). Technical data sheet 1-butyl-1-methylpyrrolidinium trifluoromethanesulfonate.

Iolitec (2012c). Technical data sheet choline dihydrogenphosphate.

Iolitec (2012d). Technical data sheet methyltrioctylammonium triflate.

Iolitec (2013a). Technical data sheet tributylmethylphosphonium methyl sulfate (CYPHOS IL-108).

Iolitec (2013b). Technical data sheet trihexyl(tetradecyl)phosphonium decanoate.

Iolitec (2014). Technical data sheet 1-methyl-3-octylimidazolim hexafluorophosphate.

Iolitec (2015a). Safety data sheet 1-Butyl-1-methylpyrrolidinium chloride.

Iolitec (2015b). Safety data sheet 1-Ethylpyridinium bis(trifluoromethylsulfonyl) imde.

Iolitec (2015c). Safety data sheet IoLiLyte 221PG.

Iolitec (2015d). Safety data sheet IoLiLyte C1EG.

Iolitec (2015e). Safety data sheet tetraoctylphosphonium bromide (CYPHOS IL166).

Iolitec (2016). Technical data sheet choline bis(trifluoromethylsulfonyl)imide.

Iolitec (2018). Technical data sheet trihexyltetradecylphosphonium bis(2,4,4trimethylpentyl)phosphinate.

Iolitect (2011). Technical data sheet 1-Ethyl-1-methylpyrrolidinium bis(trifluoromethylsulfonyl)imide.

Ishikawa, M., Sugimoto, T., Kikuta, M., Ishiko, E., and Kono, M. (2006). Pure ionic liquid electrolytes compatible with a graphitized carbon negative electrode in rechargeable lithium-ion batteries. J. Power Sources. 162, 658-662. doi:10.1016/ j.jpowsour.2006.02.077

Jiang, Y., Guo, C., Xia, H., Mahmood, I., Liu, C., and Liu, H. (2009). Magnetic nanoparticles supported ionic liquids for lipase immobilization: enzyme activity in catalyzing esterification. J. Mol. Catal. B Enzym. 58, 103-109. doi:10.1016/j. molcatb.2008.12.001

Jorge, A. B., and Hazael, R. (2016). Use of Shewanella oneidensis for energy conversion in microbial fuel cells. Macromol. Chem. Phys. 217, 1431-1438. doi:10.1002/macp.201500477

Kalčíková, G., Zagorc-Končan, J., Žnidaršič-Plazl, P., and Gotvajn, A. Ž. (2012). Assessment of environmental impact of pyridinium-based ionic liquid. Fresenius Environ. Bull. 21, 2320-2325.

Kim, J. Y., Kim, J. T., Song, E. A., Min, Y. K., and Hamaguchi, H. O. (2008). Polypyrrole nanostructures self-assembled in magnetic ionic liquid as a template. Macromolecules. 41, 2886-2889. doi:10.1021/ ma071333k

Kumar, R., Singh, L., and Zularisam, A. W. (2016). Exoelectrogens: recent advances in molecular drivers involved in extracellular electron transfer and strategies 
used to improve it for microbial fuel cell applications. Renew. Sustain. Energy Rev. 56, 1322-1336. doi:10.1016/j.rser.2015.12.029

Latała, A., Nędzi, M., and Stepnowski, P. (2009). Toxicity of imidazolium and pyridinium based ionic liquids towards algae. Bacillaria paxillifer (a microphytobenthic diatom) and Geitlerinema amphibium (a microphytobenthic blue green alga). Green Chem. 11, 1371-1376. doi:10. 1039/b901887e

Latała, A., Stepnowski, P., Nędzi, M., and Mrozik, W. (2005). Marine toxicity assessment of imidazolium ionic liquids: acute effects on the Baltic algae Oocystis submarina and Cyclotella meneghiniana. Aquat. Toxicol. 73, 91-98. doi:10.1016/j.aquatox.2005.03.008

Lee, S. H., Doan, T. T. N., Ha, S. H., and Koo, Y. M. (2007). Using ionic liquids to stabilize lipase within sol-gel derived silica. J. Mol. Catal. B Enzym. 45, 57-61. doi:10.1016/j.molcatb.2006.11.008

Lee, S. Y., Vicente, F. A., E Silva, F. A., Sintra, T. E., Taha, M., Khoiroh, I., et al. (2015). Evaluating self-buffering ionic liquids for Biotechnological applications. ACS Sustain. Chem. Eng. 3, 3420-3428. doi:10.1021/acssuschemeng.5b01155

Lozano, P., García-Verdugo, E., Karbass, N., Montague, K., De Diego, T., Burguete, M. I., et al. (2010). Supported ionic liquid-like phases (SILLPs) for enzymatic processes: continuous KR and DKR in SILLP-scCO2 systems. Green Chem. 12, 1803-1810. doi:10.1039/c0gc00076k

Łuczak, J., Jungnickel, C., Łącka, I., Stolte, S., and Hupka, J. (2010). Antimicrobial and surface activity of 1-alkyl-3-methylimidazolium derivatives. Green Chem. 12, 593-660. doi:10.1039/b921805j

Luis, P., Ortiz, I., Aldaco, R., and Irabien, A. (2007). A novel group contribution method in the development of a QSAR for predicting the toxicity (Vibrio fischeri EC50) of ionic liquids. Ecotoxicol. Environ. Saf. 67, 423-429. doi:10. 1016/j.ecoenv.2006.06.010

MacDonell, M. T., and Colwell, R. R. (1985). Phylogeny of the vibrionaceae, and recommendation for two new genera, listonella and shewanella. Syst. Appl. Microbiol. 6, 171-182. doi:10.1016/S0723-2020(85)80051-5

Marsili, E., Baron, D. B., Shikhare, I. D., Coursolle, D., Gralnick, J. A., and Bond, D. R. (2008). Shewanella secretes flavins that mediate extracellular electron transfer. Proc. Natl. Acad. Sci. U. S. A. 105, 3968-3973. doi:10.1073/pnas. 0710525105

Matzke, M., Arning, J., Ranke, J., Jastorff, B., and Stolte, S. (2010). "Design of inherently safer ionic liquids: toxicology and biodegradation," in Handbook of green chemistry. Weinheim, Germany: Wiley-VCH Verlag GmbH \& Co. KGaA, 233-298. doi:10.1002/9783527628698.hgc069

Matzke, M., Stolte, S., Arning, J., Uebers, U., and Filser, J. (2008). Imidazolium based ionic liquids in soils: effects of the side chain length on wheat (Triticum aestivum) and cress (Lepidium sativum) as affected by different clays and organic matter. Green Chem. 10, 584-659. doi:10.1039/b717811e

Missoun, F., Pérez de los Ríos, A., Ortiz-Martínez, V. M., Salar-García, M. J., Hernández-Fernández, J., and Hernández-Fernández, F. J. (2020). Discovering low toxicity ionic liquids for Sacharomyces cerevisiae by using the agar well diffusion test. Processes. 8 (9), 1163. doi:10.3390/pr8091163

Nakashima, K., Kamiya, N., Koda, D., Maruyama, T., and Goto, M. (2009). Enzyme encapsulation in microparticles composed of polymerized ionic liquids for highly active and reusable biocatalysts. Org. Biomol. Chem. 7, 2353-2358. doi:10.1039/b823064a.

Nockemann, P., Binnemans, K., Thijs, B., Parac-Vogt, T. N., Merz, K., Mudring, A. V., et al. (2009). Temperature-driven mixing-demixing behavior of binary mixtures of the ionic liquid choline bis(trifluoromethylsulfonyl)imide and water. J. Phys. Chem. B. 113, 1429-1437. doi:10.1021/jp808993t.

Ortega, J., Vreekamp, R., Marrero, E., and Penco, E. (2007). Thermodynamic properties of 1-butyl-3-methylpyridinium tetrafluoroborate and its mixtures with water and alkanols. J. Chem. Eng. Data. 52, 2269-2276. doi:10.1021/ je700294p

Papaiconomou, N., Yakelis, N., Salminen, J., Bergman, R., and Prausnitz, J. M. (2006). Synthesis and properties of seven ionic liquids containing 1-methyl-3octylimidazolium or 1-butyl-4-methylpyridinium cations. J. Chem. Eng. Data. 52, 319. doi:10.1021/je060096y

Pârvulescu, V. I., and Hardacre, C. (2007). Catalysis in ionic liquids. Chem. Rev. 107, 2615-2665. doi:10.1021/cr050948h

Pérez De Los Ríos, A., Hernández-Fernández, F. J., Zapata Henríquez, P. A., Missoun, F., Hernández-Fernández, J., Ortiz-Martínez, V., et al. (2017). Keys for Bioethanol production processes by fermentation and ionic liquid extraction. ACS Sustain. Chem. Eng. 5, 6986-6993. doi:10.1021/ acssuschemeng.7b01170

Pernak, J., Sobaszkiewicz, K., and Mirska, I. (2003). Anti-microbial activities of ionic liquids. Green Chem. 5, 52-56. doi:10.1039/b207543c

Pretti, C., Chiappe, C., Baldetti, I., Brunini, S., Monni, G., and Intorre, L. (2009). Acute toxicity of ionic liquids for three freshwater organisms: pseudokirchneriella subcapitata, Daphnia magna and Danio rerio. Ecotoxicol. Environ. Saf. 72, 1170-1176. doi:10.1016/j.ecoenv.2008.09.010

Qiu, Z., and Texter, J. (2008). Ionic liquids in microemulsions. Curr. Opin. Colloid Interface Sci. 13, 252-262. doi:10.1016/j.cocis.2007.10.005

Ranke, J., Mölter, K., Stock, F., Bottin-Weber, U., Poczobutt, J., Hoffmann, J., et al. (2004). Biological effects of imidazolium ionic liquids with varying chain lengths in acute Vibrio fischeri and WST-1 cell viability assays. Ecotoxicol. Environ. Saf. 58, 396-404. doi:10.1016/S0147-6513(03)00105-2

Ranke, J., Müller, A., Bottin-Weber, U., Stock, F., Stolte, S., Arning, J., et al. (2007). Lipophilicity parameters for ionic liquid cations and their correlation to in vitro cytotoxicity. Ecotoxicol. Environ. Saf. 67, 430-438. doi:10.1016/j.ecoenv.2006. 08.008

Rebros, M., Gunaratne, H. Q. N., Ferguson, J., Seddon, K. R., and Stephens, G. (2009). A high throughput screen to test the biocompatibility of water-miscible ionic liquids. Green Chem. 11, 402-440. doi:10.1039/b815951c

Romero, A., Santos, A., Tojo, J., and Rodríguez, A. (2008). Toxicity and biodegradability of imidazolium ionic liquids. J. Hazard Mater. 151, 268-273. doi:10.1016/j.jhazmat.2007.10.079

Russina, O., Caminiti, R., Triolo, A., Rajamani, S., Melai, B., Bertoli, A., et al. (2013). Physico-chemical properties and nanoscale morphology in $\mathrm{N}$-alkyl-Nmethylmorpholinium dicyanamide room temperature ionic liquids. J. Mol. Liq. 187, 252-259. doi:10.1016/j.molliq.2013.08.002

Sakaebe, H., Matsumoto, H., and Tatsumi, K. (2005). Discharge-charge properties of $\mathrm{Li} / \mathrm{LiCoO} 2$ cell using room temperature ionic liquids (RTILs) based on quaternary ammonium cation - effect of the structure. J. power sources. 146, 693-697. doi:10.1016/j.jpowsour.2005.03.071

Santa Cruz Biotechnology, Inc. (2012). 1,2,3-Trimethylimidazolium methyl sulfate. Tech. Data Sheet.

Schrekker, H. S., Gelesky, M. A., Stracke, M. P., Schrekker, C. M. L., Machado, G., Teixeira, S. R., et al. (2007). Disclosure of the imidazolium cation coordination and stabilization mode in ionic liquid stabilized gold(0) nanoparticles. J. Colloid Interface Sci. 316, 189-195. doi:10.1016/j.jcis.2007.08.018

Sena, D. W., Kulacki, K. J., Chaloner, D. T., and Lamberti, G. A. (2010). The role of the cell wall in the toxicity of ionic liquids to the alga Chlamydomonas reinhardtii. Green Chem. 12, 1066-1071. doi:10.1039/c000899k

Shim, Y., and Kim, H. J. (2009). Solvation of carbon nanotubes in a roomtemperature ionic liquid. ACS Nano. 3, 1693-1702. doi:10.1021/ nn900195b

Sigma Aldrich (2006). Safety data sheet methyltrioctylammonium chloride. St. Louis, MO: Sigma Aldrich.

Stepnowski, P., Składanowski, A. C., Ludwiczak, A., and Łaczyńska, E. (2004). Evaluating the cytotoxicity of ionic liquids using human cell line HeLa. Hum. Exp. Toxicol. 23, 513-517. doi:10.1191/0960327104ht480oa

Stolte, S., Abdulkarim, S., Arning, J., Blomeyer-Nienstedt, A. K., Bottin-Weber, U., Matzke, M., et al. (2008). Primary biodegradation of ionic liquid cations, identification of degradation products of 1-methyl-3-octylimidazolium chloride and electrochemical wastewater treatment of poorly biodegradable compounds. Green Chem. 10, 214-222. doi:10.1039/b713095c

Stolte, S., Arning, J., Bottin-Weber, U., Müller, A., Pitner, W. R., Welz-Biermann, U., et al. (2007a). Effects of different head groups and functionalised side chains on the cytotoxicity of ionic liquids. Green Chem. 9, 760-776. doi:10.1039/ b615326g

Stolte, S., Matzke, M., Arning, J., Böschen, A., Pitner, W. R., Welz-Biermann, U., et al. (2007b). Effects of different head groups and functionalised side chains on the aquatic toxicity of ionic liquids. Green Chem. 9, 1170-1179. doi:10.1039/ b711119c.

Suo, H., Xu, L., Xu, C., Chen, H., Yu, D., Gao, Z., et al. (2018). Enhancement of catalytic performance of porcine pancreatic lipase immobilized on functional ionic liquid modified Fe3O4-Chitosan nanocomposites. Int. J. Biol. Macromol. 119, 624-632. doi:10.1016/j.ijbiomac.2018.07.187

Toral, A. R., de los Ríos, A. P., Hernández, F. J., Janssen, M. H. A., Schoevaart, R., van Rantwijk, F., et al. (2007). Cross-linked Candida Antarctica lipase B is active 
in denaturing ionic liquids. Enzym. Microb. Technol. 40, 1095-1099. doi:10. 1016/J.ENZMICTEC.2006.08.027

Varia, J., Zegeye, A., Roy, S., Yahaya, S., and Bull, S. (2014). Shewanella putrefaciens for the remediation of $\mathrm{Au} 3+, \mathrm{Co} 2+$ and $\mathrm{Fe} 3+$ metal ions from aqueous systems. Biochem. Eng. J. 85, 101-109. doi:10.1016/j.bej.2014.02.002

Ventura, S. P. M., de Barros, R. L. F., Sintra, T., Soares, C. M. F., Lima, Á. S., and Coutinho, J. A. P. (2012a). Simple screening method to identify toxic/non-toxic ionic liquids: agar diffusion test adaptation. Ecotoxicol. Environ. Saf. 83, 55-62. doi:10.1016/j.ecoenv.2012.06.002

Ventura, S. P. M., Marques, C. S., Rosatella, A. A., Afonso, C. A. M., Gonçalves, F., and Coutinho, J. A. P. (2012b). Toxicity assessment of various ionic liquid families towards Vibrio fischeri marine bacteria. Ecotoxicol. Environ. Saf. 76, 162-168. doi:10.1016/j.ecoenv.2011.10.006

Ventura, S. P. M., Gonçalves, A. M. M., Sintra, T., Pereira, J. L., Gonçalves, F., and Coutinho, J. A. P. (2013). Designing ionic liquids: the chemical structure role in the toxicity. Ecotoxicology. 22, 1-12. doi:10.1007/ s10646-012-0997-x

Viboud, S., Papaiconomou, N., Cortesi, A., Chatel, G., Draye, M., and Fontvieille, D. (2012). Correlating the structure and composition of ionic liquids with their toxicity on Vibrio fischeri: a systematic study. J. Hazard Mater. 215-216, 40-48. doi:10.1016/j.jhazmat.2012.02.019

Walker, A. (2009). Solvents. International publication number WO2009034329A1.

Wang, L., Chen, S., Ding, Y., Zhu, Q., Zhang, N., and Yu, S. (2018). Biofabrication of morphology improved cadmium sulfide nanoparticles using Shewanella oneidensis bacterial cells and ionic liquid: for toxicity against brain cancer cell lines. J. Photochem. Photobiol. B Biol. 178, 424-427. doi:10.1016/j.jphotobiol. 2017.11.007

Webster, D. P., TerAvest, M. A., Doud, D. F. R., Chakravorty, A., Holmes, E. C., Radens, C. M., et al. (2014). An arsenic-specific biosensor with genetically engineered Shewanella oneidensis in a bioelectrochemical system. Biosens. Bioelectron. 62, 320-324. doi:10.1016/j.bios.2014.07.003

Wei, H., Wu, X. S., Zou, L., Wen, G. Y., Liu, D. Y., and Qiao, Y. (2016). Amineterminated ionic liquid functionalized carbon nanotubes for enhanced interfacial electron transfer of Shewanella putrefaciens anode in microbial fuel cells. J. Power Sources. 315, 192-198. doi:10.1016/j. jpowsour.2016.03.033

Welton, T. (1999). Room-temperature ionic liquids. Solvents for synthesis and catalysis. Chem. Rev. 99, 2071-2084. doi:10.1021/cr980032t

Wood, N., Ferguson, J. L., Gunaratne, H. Q. N., Seddon, K. R., Goodacre, R., and Stephens, G. M. (2011). Screening ionic liquids for use in biotransformations with whole microbial cells. Green Chem. 13, 1843-1851. doi:10.1039/c0gc00579g

Wood, N., and Stephens, G. (2010). Accelerating the discovery of biocompatible ionic liquids. Phys. Chem. Chem. Phys. 12, 1670-1674. doi:10.1039/b923429b.

Xiang, X., Suo, H., Xu, C., and Hu, Y. (2018). Covalent immobilization of lipase onto chitosan-mesoporous silica hybrid nanomaterials by carboxyl functionalized ionic liquids as the coupling agent. Colloids Surf. B Biointerfaces. 165, 262-269. doi:10.1016/j.colsurfb.2018.02.033
Yang, C., Sun, Q., Qiao, T., and Li, Y. (2003). Ionic liquid doped polymer light-emitting electrochemical cells. J. Phys. Chem. B. 107, 12981-12988. doi:10.1021/jp034818t

Ye, C., Liu, W., Chen, Y., and Yu, L. (2001). Room-temperature ionic liquids: a novel versatile lubricant. Chem. Commun. 21, 2244-2245. doi:10.1039/b106935g

Zein El Abedin, S., Moustafa, E. M., Hempelmann, R., Natter, H., and Endres, F. (2006). Electrodeposition of nano- and macrocrystalline aluminium in three different air and water stable ionic liquids. ChemPhysChem. 7, 1535-1543. doi:10.1002/cphc.200600095

Zhang, C. L., Yu, Y. Y., Fang, Z., Naraginti, S., Zhang, Y., and Yong, Y. C. (2018). Recent advances in nitroaromatic pollutants bioreduction by electroactive bacteria. Process Biochem. 70, 129-135. doi:10.1016/j.procbio.2018.04.019

Zhang, S., Zhou, Q., Lu, X., Song, Y., and Wang, X. (2016). "Solubility and diffusivity of 1-butyl-3-methylimidazolium 1,1,2,2tetrafluoroethanesulfonate mixtures," in Physicochemical Properties of ionic liquid mixtures. Dordrecht, Netherlands: Springer, 588-599. doi:10.1007/978-94-017-7573-1_46

Zhao, C., Wang, Y., Shi, F., Zhang, J., and Zhu, J. J. (2013). High biocurrent generation in shewanella-inoculated microbial fuel cells using ionic liquid functionalized graphene nanosheets as an anode. Chem. Commun. 49, 6668-6670. doi:10.1039/c3cc42068j

Zhou, T., Chen, L., Ye, Y., Chen, L., Qi, Z., Freund, H., et al. (2012). An overview of mutual solubility of ionic liquids and water predicted by COSMO-RS. in Industrial and engineering chemistry research. Washington, D.C: American Chemical Society, 6256-6264. doi:10.1021/ie202719z

Zhou, Y., Roberson, A. J., and Hillhouse, H. H, B. D. (2002). US7638636B2 phosphonium and imidazolium salts and methods of their preparation. Google Patents.

Zou, B., Song, C., Xu, X., Xia, J., Huo, S., and Cui, F. (2014). Enhancing stabilities of lipase by enzyme aggregate coating immobilized onto ionic liquid modified mesoporous materials. Appl. Surf. Sci. 311, 62-67. doi:10.1016/j.apsusc.2014.04. 210

Zou, L., Huang, Y., Long, Z., and Qiao, Y. (2019). On-going applications of Shewanella species in microbial electrochemical system for bioenergy, bioremediation and biosensing. World J. Microbiol. Biotechnol. 35, 9. doi:10. 1007/s11274-018-2576-7

Conflict of Interest: The authors declare that the research was conducted in the absence of any commercial or financial relationships that could be construed as a potential conflict of interest.

Copyright () 2020 Kebaili, Pérez de los Ríos, Salar, Ortiz Martínez, Kameche, Hernández and Hernández Ferández. This is an open-access article distributed under the terms of the Creative Commons Attribution License (CC BY). The use, distribution or reproduction in other forums is permitted, provided the original author(s) and the copyright owner(s) are credited and that the original publication in this journal is cited, in accordance with accepted academic practice. No use, distribution or reproduction is permitted which does not comply with these terms. 